$$
\text { UNIVERSIDADE DE SÃO PAULO }
$$

FACULDADE DE MEDICINA VETERINARIA E ZOOTECNIA

RAQUEL HARUE FUKUMORI ALMEIDA SOUZA

Avaliação sérica de estrógeno e progesterona por método de imunoensaio multianalito em cadelas durante o ciclo estral

São Paulo/SP

2015 


\section{Avaliação sérica de estrógeno e progesterona por método de imunoensaio multianalito em cadelas durante o ciclo estral}

Dissertação apresentada ao Programa de Pós-Graduação Reprodução Animal da Faculdade de Medicina Veterinária e Zootecnia da Universidade de São Paulo para obtenção do título de Mestre em Ciências

Departamento:

Reprodução Animal

Área de concentração:

Reprodução Animal

Orientador:

Prof. Dr. Claudio Alvarenga de Oliveira 
Autorizo a reprodução parcial ou total desta obra, para fins acadêmicos, desde que citada a fonte.

DADOS INTERNACIONAIS DE CATALOGAÇÃO-NA-PUBLICAÇÃO

(Biblioteca Virginie Buff D’Ápice da Faculdade de Medicina Veterinária e Zootecnia da Universidade de São Paulo)

Souza, Raquel Harue Fukumori Almeida

Avaliação sérica de estrógeno e progesterona por método de imunoensaio multianalito em cadelas durante o ciclo estral / Raquel Harue Fukumori Almeida Souza. -- 2015

57 p. il.

Dissertação (Mestrado) - Universidade de São Paulo. Faculdade de Medicina Veterinária e Zootecnia. Departamento de Reprodução Animal, São Paulo, 2015.

Programa de Pós-Graduação: Reprodução Animal.

Área de concentração: Reprodução Animal.

Orientador: Prof. Dr. Claudio Alvarenga de Oliveira. 


\section{COMISSÃO ETICA}

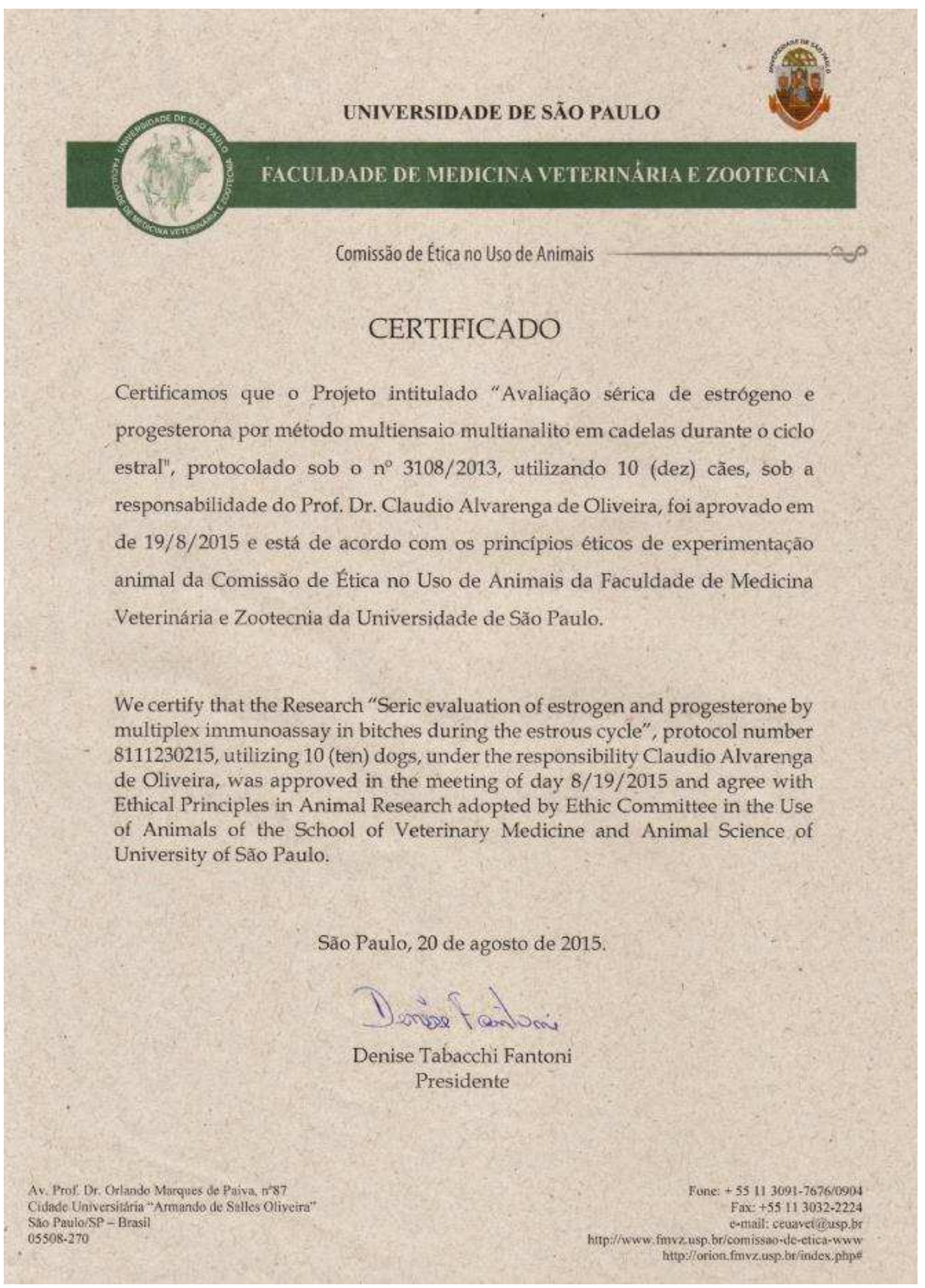




\section{FOLHA DE AVALIAÇÃO}

Autor(a): Raquel Harue Fukumori Almeida Souza

Título: Avaliação sérica de estrógeno e progesterona por método multiensaio multianalito em cadelas durante o ciclo estral

Dissertação apresentada ao Programa de Reprodução Animal da Faculdade de Medicina Veterinária e Zootecnia da Universidade de São Paulo para obtenção do título de Mestre em Ciências

Data:

Banca Examinadora

$\operatorname{Prof}(\mathrm{a}) \cdot \operatorname{Dr}(\mathrm{a}) .:$

Instituição: Julgamento:

Prof(a). Dr(a).:

Instituição: Julgamento:

Prof(a). Dr(a).:

Instituição: Julgamento: 


\section{DEDICATÓRIA}

No início da pós-graduação, este trabalho seria dedicado a algumas das pessoas mais importantes da minha vida:

Ao Arthur, marido e cumplice, sem você com certeza não teria conseguido. Obrigada por me amar, por ser meus olhos quando pude enxergar e por ser meus lábios quando não pude respirar. A você todo meu amor, te amo hoje amanhã e sempre!

Ao Davizinho, filho querido, que contribuiu muito para realizar este trabalho, mesmo que para ele, ter me ajudado significou ficar uns dias na casa da vovó e da bá. Por você meu filho, todo o esforço é recompensado com um abraço de urso e um beijo na mamãe, quando o desespero bate forte. Você é a força que me faz levantar todos os dias. Mamãe te ama hoje amanhã e sempre!

Aos meus pais, Hélio e Harumi, por todo amor e toda dedicação que sempre tiveram comigo. A vocês muito obrigada por todos os sacrifícios que vocês fizeram. Obrigada por me ensinarem os maiores valores da vida. Amo vocês!!

À minha irmã, Tikinha, por sempre estar ao meu lado. Por me apoiar em cada decisão, e por me ajudar sempre que precisei. Por ser assim, minha irmã!!! Te amo!!

Ao Tibi (in memoriam) que foi minha primeira paixão de quatro patas, agradeço por me inspirar a ser veterinária, por me acompanhar durante toda sua vida de forma tão fiel e leal. Um dia nos encontraremos denovo. E ao Joca, obrigada por me ensinar o que é ter um gato em casa e por, literalmente, estar sempre ao meu lado. Obrigada por fazer parte da nossa família e por ser um "irmão" mais velho tão dedicado (se prepara que logo mais teremos mais uma companhia!!)

Porém, no fim da pós graduação, minha dedicatória aumentou mais um pouco:

Ao "bebê", que infelizmente não tivemos tempo hábil de colocar seu nome nesta dedicatória, pois ainda não descobrimos se será a Luiza ou o João. Mas com certeza na defesa já teremos seu nome definido. A você, meu mais novo amor, obrigada por me acompanhar na fase final da dissertação. Não nos conhecemos ainda, mas meu amor por você já é infinito! 


\section{AGRADECIMENTOS}

Ao meu orientador, prof. Claudio Alvarenga de Oliveira por ter me acolhido em seu departamento, e por ter me proporcionado a oportunidade de realizar mais esta etapa de minha vida. Obrigada pela oportunidade e pela paciência comigo.

À Priscila Viau Furtado, por abrir as portas do seu laboratório para que este sonho se realizasse. Obrigada pela paciência, pela dedicação e principalmente pela amizade que acabamos conquistando.

Ao Canil Espaço Ducão, agradeço à Marcela e ao Zé por serem tão parceiros e por me ajudarem nas coletas. E um agradecimento especial para as "meninas", Jenny, Bonna, Bina, Dora, Zuka, Quick e Cléo, por terem sido tão pacientes e por cederem um pouquinho de cada uma para que todo o trabalho fosse concluído.

À profa. Marcia Marques Jericó, por estar ao meu lado desde o início da minha graduação, sempre me incentivando e "puxando minha orelha" quando necessário. Obrigada por todas as orientações (de vida e acadêmicas), por todo carinho, e por estar sempre por perto. Você sempre será minha fonte de inspiração!

A Merck-Millipore, por ter cedido o laboratório para que o experimento pudesse ter continuidade. Em especial, ao Matheus que tão pacientemente nos explicou e nos ensinou tudo sobre o ensaio e sobre a metodologia.

À Patrícia Rotta Lopes, que me ajudou nos ensaios e que sempre me acalmou quando a ansiedade falava mais alto.

Aos amigos, Rafael, Madalena e Bernardo, por serem amigos tão presentes em nossas vidas. Obrigada por nos aguentarem!!! 
"Ainda que eu falasse a língua dos homens, E falasse a língua dos anjos, Sem amor eu nada seria" Renato Russo 


\section{RESUMO}

ALMEIDA SOUZA, R. H. F. Avaliação sérica de estrógeno e progesterona por método de imunoensaio multianalito em cadelas durante o ciclo estral. [Seric evaluation of estrogen and progesterone by multiplex immunoassay in bitches during the estrous cycle]. 2015. 57f. Dissertação (Mestrado em Ciências) - Faculdade de Medicina Veterinária e Zootecnia, Universidade de São Paulo, São Paulo, 2015

O trabalho teve como objetivo avaliar a concentração sérica de estrógeno e progesterona em cadelas durante o ciclo estral por imunoensaio multianalito (Luminex ${ }^{\circledR} \times \mathrm{XMP}^{\circledR}$ ), visando avaliar a aplicabilidade fisiológica e comparar os resultados obtidos com os valores já estabelecidos na literatura pelo método de radioimunoensaio (RIE). Foram utilizadas 7 cadelas da raça Border Collie, residentes do Canil Espaço Ducão (Valinhos/SP) de diferentes idades e ao primeiro sinal de sangramento vulvar (proestro/estro) foram coletadas amostras a cada 48 hs e ao seu termino (diestro), foi realizado coletas semanalmente (intervalo de 7 dias) durante aproximadamente 3 semanas. Houve correlação positiva apenas entre os valores de progesterona na fase de proestro/estro $(p=0,001)$. Apesar de não ter ocorrido correlação entre as outras fases, as medias dos valores séricos de estradiol e progesterona foram estatisticamente significantes, em ambas as fases, sendo os valores obtidos pelo Luminex ${ }^{\circledR}$ maiores que os obtidos pelo RIE. Os valores de progesterona confirmaram os dados fisiológicos esperados em ambas as metodologias, porém os valores de estradiol não foram compatíveis com o esperado fisiologicamente, exceto quando analisados a partir das medias globais em ambas as fases. Novos estudos de validação laboratorial serão necessários para confirmar a validação fisiológica, principalmente no perfil da progesterona. Podemos concluir ainda que os valores de referência para 0 Luminex $^{\circledR}$ devem ser diferentes dos valores já estabelecidos pelo RIE para ambos os hormônios testados.

Palavras-chave: Cadelas. Estradiol. Progesterona. RIE. Luminex ${ }^{\circledR}$ 


\section{ABSTRACT}

ALMEIDA SOUZA, R. H. F. Seric evaluation of estrogen and progesterone by multiplex immunoassay in bitches during the estrous cycle [Avaliação sérica de estrógeno e progesterone por método de imunoensaio multianalito em cadelas durante o ciclo estral]. 2015. 57f. Dissertação (Mestrado em Ciências) - Faculdade de Medicina Veterinária e Zootecnia, Universidade de São Paulo, São Paulo, 2015

The study aimed to evaluate the serum concentration of estrogen and progesterone in female dogs during the estrous cycle by multiplex immunoassay (Luminex $\AA \mathrm{xMAP} \AA$ ), to evaluate the physiological applicability and compare the results with the values established in the literature by radioimmunoassay (RIA). We used seven Border Collie bitches, residents in Kennel Espaço Ducão (Valinhos/SP), of different ages and for the first sign of vulvar bleeding (proestrus/estrus) samples were collected every 48 hours and its end (diestrus) were collected weekly (every 7 days) for about three weeks. There was a positive correlation only between progesterone values in the proestrus/estrus phase $(p=0.001)$. Despite having not occurred correlation between the other phases, the median of serum estradiol and progesterone values were statistically significant in both phases, the values obtained by Luminex $\AA$ is higher than by RIA. Progesterone values confirmed the expected physiological data in both methods, however estradiol values were not physiologically compatible with the expected, except when analyzed from the global mean in both phases. A laboratory validation studies will be needed to confirm the physiological validation, especially in progesterone profile, and we can conclude that the reference values for the Luminex® should be different from the values established by RIE for both hormones tested.

Keys-words: Bitches. Estrogen. Progesterone. RIA. Luminex® 


\section{LISTA DE GRÁFICOS}

Gráfico 1 - Representação gráfica da curva de paralelismo obtida para estradiol utilizando matriz sérica.

Gráfico 2 - Representação gráfica das concentrações séricas de progesterona por RIE obtidas durante o período de proestro/estro e diestro dos animais A-G..37

Gráfico 3 - Representação gráfica das concentrações séricas de progesterona por RIE dos animais $\mathrm{B}$ e $\mathrm{C}$, com sangramento vaginal prolongado.

Gráfico 4 - Representação gráfica da concentração sérica de progesterona por RIE do animal D

Gráfico 5 - Representação gráfica das concentrações séricas de progesterona por Luminex® obtidas durante o período de proestro/estro e diestro dos animais $A-G$.

Gráfico 6 - Representação gráfica das médias (土EPM) dos valores de progesterona por RIE e LUM.

Gráfico 7 - Representação gráfica das médias ( \pm EPM) dos valores de progesterona por RIE. A linha demarca o valor médio no D0.

Gráfico 8 -Representação gráfica das médias ( $\pm E P M)$ dos valores de progesterona por Luminex®. A linha demarca o valor médio no D0.

Gráfico 9 - Representação grafica dos valores médios ( $\pm E P M)$ de progesterona dosado por radioimunoensaio e Luminex $\AA$, nas fases de proestro/estro e na fase de diestro.

Gráfico 10 - Representação gráfica da correlação de Pearson obtida entre a progesterona dosada pelo RIE e pelo Luminex®.

Gráfico 11 -- Representação gráfica da correlação positiva entre o RIE e o LUM durante a fase de proestro/estro na dosagem de progesterona.....

Gráfico 12 - Representação gráfica da ausência de correlação entre o RIE e LUM durante o diestro na dosagem de progesterona.

Gráfico 13 - Representação gráfica das médias (土EPM) dos valores de estradiol por radioimunoensaio.

Gráfico 14 - Representação gráfica das médias (土EPM) dos valores de estradiol por Luminex®...

Gráfico 15 - Representação gráfica dos valores médios („EPM) de progesterona dosado por radioimunoensaio e Luminex®, nas fases de proestro/estro e na fase de diestro.

Gráfico 16 - Representação gráfica dos valores de estradiol e progesterona obtidos pelo RIE e pelo LUM do animal A 
Gráfico 17 - Representação gráfica dos valores de estradiol e progesterona obtidos pelo RIE e pelo LUM do animal B.

Gráfico 18 - Representação gráfica dos valores de estradiol e progesterona obtidos pelo RIE e pelo LUM do animal C.

Gráfico 19 - Representação gráfica dos valores de estradiol e progesterona obtidos pelo RIE e pelo LUM do animal D.

Gráfico 20 - Representação gráfica dos valores de estradiol e progesterona obtidos pelo RIE e pelo LUM do animal E.

Gráfico 21 - Representação gráfica dos valores de estradiol e progesterona obtidos pelo RIE e pelo LUM do animal F.

Gráfico 22 - Representação gráfica dos valores de estradiol e progesterona obtidos pelo RIE e pelo LUM do animal $\mathrm{G}$.

Gráfico 23 - Representação gráfica da correlação de Spearman obtida entre o estradiol dosado por RIE e por Luminex®.

Gráfico 24 - Representação gráfica da ausência de correlação entre o RIE e LUM durante a fase de proestro/estro na mensuração de estradiol.

Gráfico 25 - Representação gráfica da ausência de correlação entre RIE e LUM durante a fase de diestro na mensuração de estradiol. 


\section{LISTA DE TABELAS}

Tabela 1 - Controle de qualidade da Progesterona Sérica (Immunotech®) ….................34

Tabela 2 - Controle de qualidade do Estradiol Ultra Sensível (Immunotech®) .............. 35

Tabela 3 - Médias dos valores séricos ( $\pm E P M)$ de progesterona por RIE e LUM nas fases de proestro/estro e diestro.

Tabela 4 - Médias dos valores séricos (士EPM) de estradiol por RIE e LUM nas fases de proestro/estro e diestro 


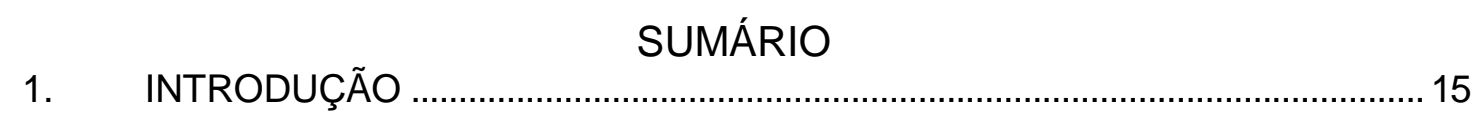

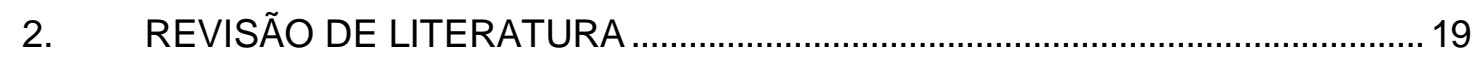

2.1. Ciclo Estral da Cadela ...................................................................................... 19

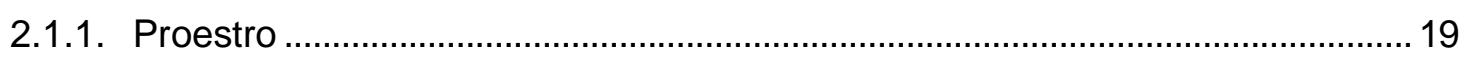

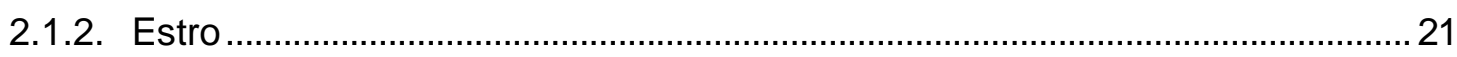

2.1.3. Diestro

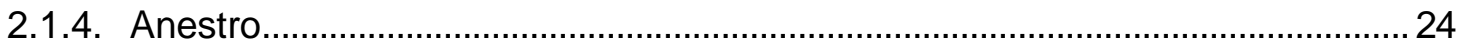

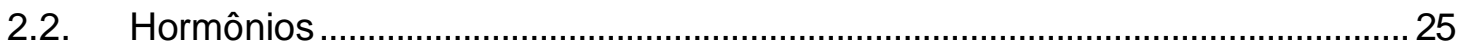

2.3. Metodologia de Dosagem Hormonal .............................................................. 26

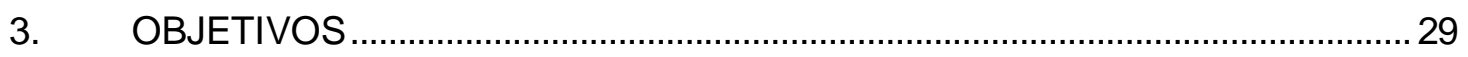

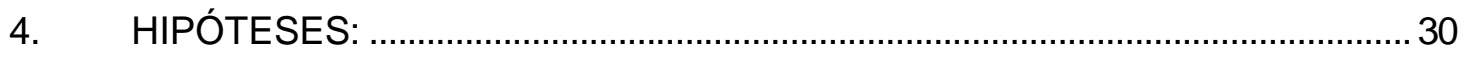

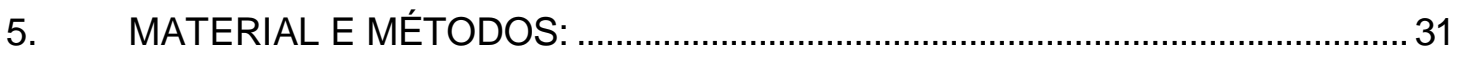

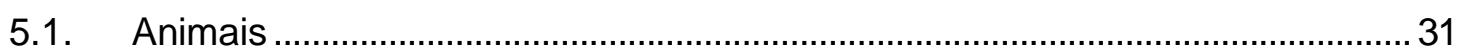

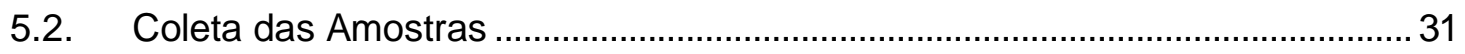

5.3. Dosagens Hormonais ...................................................................................... 32

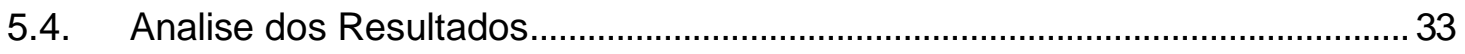

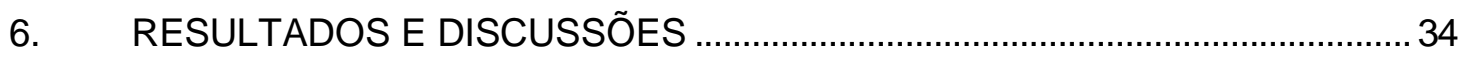

6.1. Parâmetros de qualidade dos ensaios hormonais ............................................... 34

6.2. Validação laboratorial do Kit Comercial Ultra Sensitive Estradiol por radioimmunoensaio $(I m m u n o t e c h \Theta)$................................................................. 35

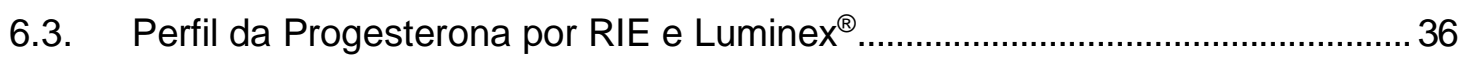

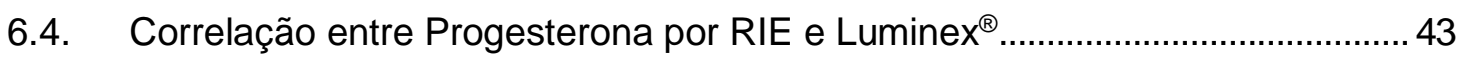

6.5. Perfil do Estradiol por RIE e Luminex ${ }^{\circledR}$............................................................. 45

6.6. Correlação entre Estradiol por RIE e Luminex ${ }^{\circledR}$ ……………………………...... 50

6.7. Validação Fisiológica.............................................................................................. 53

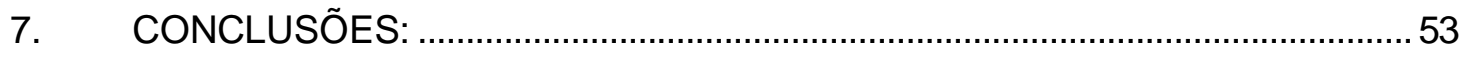

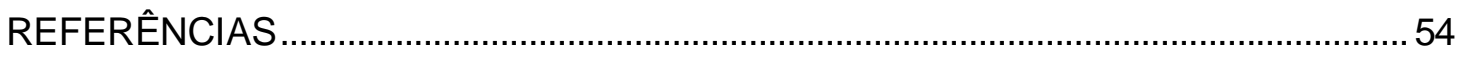




\section{INTRODUÇÃO}

O conhecimento das particularidades reprodutivas na espécie canina apresenta elevado interesse pois, além desses animais serem de companhia, são utilizados também como modelos experimentais para outras espécies de canídeos e para o homem (DERRUSSI; LOPES, 2009).

Em seres humanos, a diabetes gestacional nas mulheres é decorrente das flutuações hormonais durante a gestação. Ryan e Enns (1988), observaram em adipócitos de ratos, que durante a gestação a ligação da insulina ao seu receptor foi normal, porem o transporte de glicose foi reduzido. Sendo que a ligação máxima ao receptor foi observada com o aumento do estradiol, e a progesterona e o cortisol reduziram esta ligação. A prolactina e o lactogênio placentário reduziram o transporte de glicose, porém não alteram a ligação da insulina ao seu receptor. Nas cadelas, o aumento da progesterona sérica durante 0 diestro pode predispor 0 aparecimento de diabetes, por promover um efeito antagônico à insulina, reduzindo sua ligação com seu receptor e o transporte de glicose nos tecidos alvos (RYAN; ENNS, 1988), além de promover a liberação de hormônio do crescimento $(\mathrm{GH})$ pelas glândulas mamárias, que reduz a concentração dos receptores de insulina, reduzindo a captação de glicose (RIJNBERK; KOOISTRA; MOL, 2003). Portanto em cadelas inteiras, com diagnostico de diabetes, o estabelecimento da fase do ciclo estral é de suma importância para o manejo clinico. O entendimento do ciclo reprodutivo das cadelas pode ser útil também no manejo reprodutivo.

Técnicas de reprodução assistida, podem auxiliar no manejo das colônias de cães, no resgate de material genético de indivíduos inférteis ou geneticamente superiores, idosos ou em estado terminal (DERRUSSI; LOPES, 2009). A inseminação artificial é uma biotécnica que pode ser utilizada como método alternativo quando há impossibilidade de realizar a monta natural, por problemas anatômicos ou comportamentais, ou ainda quando há utilização de sêmen congelado. Além de propiciar a rápida disseminação do material 
genético dos machos, a preservação da sanidade dos reprodutores, e na redução do estresse no transporte destes animais (SILVA; SILVA; CARDOSO, 2001).

Para o sucesso da inseminação artificial, o acompanhamento do ciclo estral da cadela é imprescindível. Sendo a determinação do momento ideal para realizar a inseminação uma das chaves para o sucesso (SILVA; SILVA; CARDOSO, 2001). Os aspectos relacionados a ovulação na espécie canina apresentam peculiaridades (DERRUSSI; LOPES, 2009). Uma vez que os oócitos ovulam após dois dias do pico de LH em um estado imaturo, e que precisam de pelo menos 48 horas para estarem aptos a serem fertilizados (LEVY; FANTBONNE, 2007).

Para o acompanhamento do estro na cadela, os sinais clínicos como o edema de vulva, a quantidade e o aspecto da descarga vaginal (mais ou menos hemorrágico), o sinal de Amantea (a fêmea vira a cauda para o lado quando se faz uma pressão na região perineal), e a aceitação da monta pelo macho, não são precisos para determinar o momento da ovulação (ENGLAND; CONCANNON, 2002). A citologia vaginal também não identifica o momento exato da ovulação, apenas informa que a ovulação já ocorreu. $E$ a vaginoscopia também não consegue determinar o momento exato da ovulação, além de necessitar de equipamento de custo elevado e capacitação profissional para manuseá-lo (LEVY; FANTBONNE, 2007). O momento exato da ovulação é difícil de ser determinado, mas pode ser estimado pela mensuração do LH ou da progesterona (JOHNSTON; KUKUSTRITZ; OLSON, 2001) Dosagens de LH seriam o ideal, porem seriam necessárias diversas mensurações, tornando-o dispendioso, e alguns países não há kits comerciais disponíveis. Sendo assim, England and Concannon (2002), estimaram que a dosagem de progesterona seria um método indireto para prever a hora da ovulação e o tempo de maturação do oócito, uma vez que sua concentração aumenta antes e após o pico de LH durante semanas.

A dosagem de progesterona é hoje uma pratica rotineira (JOHNSTON; KUKUSTRITZ; OLSON, 2001). Com a habilidade de desenvolvimento de 
anticorpos específicos contra hormônios esteroides e proteicos surge 0 radioimunoensaio (RIA) no início da década de 50 (BENSON; YALLOW, 1960). Permitindo assim coletas seriadas para estabelecer os padrões de secreções hormonais ao logo do tempo (FURTADO, 2007).

O radioimunoensaio se tornou o método analítico padrão para detecção de analítos biológicos por décadas, devido a sua elevada sensibilidade, apesar dos riscos para a saúde com o descarte do material radioativo. Em busca de uma alternativa, surgiu o ELISA (enzyme-linked immunosorbent assay), na década de 70 (HOUSER, 2012), que também visa a ligação antígeno-anticorpo, porem diferentemente do RIA, a leitura é baseada em uma reação enzimática resultando em uma reação colorimétrica que pode ser lida em um espectrofotômetro (ENGVALL; PERLMANN, 1971). Comparado ao RIA, o ELISA possui algumas vantagens, pois não necessita de licenças especiais em decorrência do material radioativo, os ensaios podem ser automatizados permitindo elevado rendimento das amostras pois há a separação dos ligantes livres dos ligados e geralmente necessita de uma pequena quantidade de amostra, permitindo experimentos com animais de laboratório. O tempo dispendido no ELISA é bem menor quando comparado ao RIA e é possível atingir dois epitopos do mesmo peptídeo simultaneamente, sendo denominado método de ELISA sanduiche, aumentando a especificidade e a acurácia da metodologia (KURHE et al, 2015).

O RIE e o ELISA necessitam de um pré tratamento do plasma, como a extração por solventes orgânicos (como o etanol) ou extração por fase solida (com material não polar, C18) para remover substancias interferentes (BAK et al., 2014a, 2014b). A grande vantagem do RIE é ser uma técnica relativamente simples e rápida de desenvolver, uma vez que empregam anticorpos policlonais, que pode ser preparado de forma relativamente fácil. Enquanto 0 ELISA é baseado em anticorpos monoclonais, que é trabalhoso e muitas vezes sem êxito com relação à afinidade (KURHE et al, 2015).

Uma nova técnica que permite a quantificação simultânea de diversos analítos foi introduzida recentemente. Esta tecnologia denominada Luminex ${ }^{\circledR}$ é 
baseada em um anticorpo revestido com grânulos magnéticos codificados pela tonalidade de cor, que se ligam a vários ligantes diferentes (dependendo do anticorpo), e são detectados por uma técnica de citometria de fluxo especializado. E apesar do conceito promissor, o maior desafio da técnica multiplex é estabelecer a especificidade e a sensibilidade (BAK et al., 2014a, 2014b). A tecnologia Luminex ${ }^{\circledR}$ permite a mensuração simultâneas de uma série de analítos, como testes alérgicos, marcadores cardíacos e oncológicos, doenças autoimunes, doenças infecciosas, marcadores metabólicos e endócrinos e citocinas inflamatórias (MCCOY; ELSHAL, 2006).

O trabalho visou implementação de um novo método multianalise de dosagens hormonais sem utilização de material radioativo. Com este novo método será possível a detecção simultânea de diversos hormônios, diminuindo o tempo gasto para dosagem, sendo necessário uma pequena quantidade de amostra (10 a $50 \mu \mathrm{L}$ ), com menores e mais consistentes CVs (coeficientes de variação), o que permite a dosagem das amostras em simplicata, proporcionando uma significativa redução de custos. Alguns trabalhos utilizaram a tecnologia Luminex ${ }^{\circledR}$ em estudos com plasma seminal de ratos (GOPICHANDRAN et al., 2006) e em cadelas com piometra (KARLSSON et al., 2012), porém não há relatos da utilização desta metodologia para quantificar hormônios esteroidais, e, portanto, até o momento não tinha sido avaliada sua aplicabilidade fisiológica, nem tampouco estabelecida faixa de referência para o método. 


\section{REVISÃO DE LITERATURA}

\subsection{Ciclo Estral da Cadela}

O ciclo estral das cadelas possui características distintas de outras espécies domesticas, sendo monoéstricas não sazonais e assim, ovulam de uma a duas vezes por ano. São multíparas e geralmente o primeiro ciclo ocorre entre 6 a 13 meses de idade, podendo variar de acordo com a raça e o porte do animal. $O$ intervalo entre estros também varia entre 5 a 11 meses. Nas cadelas, o ciclo é dividido em quatro fases: proestro, estro, diestro e anestro (EVANS; COLE, 1931). As fases do proestro e estro se assemelham a fase proliferativa e possuem o diestro é semelhante entre as gestantes e as não gestantes, correspondendo à fase luteínica do ciclo, além de uma fase de quiescência (anestro) de vários meses (CONCANNON, 2011).

\subsubsection{Proestro}

Possui duração que varia entre 6 a 11 dias, com média de 9 dias (NELSON; FELDMAN, 2004). Seu início é caracterizado pela descarga vaginal serosanguinolenta acompanhada de edema vulvar (CONCANNON, 2011). No decorrer do proestro a vulva fica edemaciada e hipertrofiada, a cérvice dilatada, o endométrio espessado e há aumento na atividade glandular e no crescimento dos ductos e túbulos da glândula mamaria (NELSON; FELDMAN, 2004). A secreção vaginal pode ou não estar associada a descarga sanguinolenta, resultado da diapedese dos eritrócitos e da ruptura dos capilares no endométrio 
(JOHNSTON et al, 2001). Há também produção de ferormônios, liberados na secreção vaginal, pelas glândulas adanais e pela urina, que atraem os machos, porem nesta fase, a fêmea não é receptiva à monta (GOODWIN et al, 1979).

O esfregaço vaginal, no início à metade do proestro geralmente é caracterizado pela presença de eritrócitos e se parece muito com o anestro em função da presença de células parabasais, intermediarias, neutrófilos e bactérias e no fim do proestro, as células epiteliais são substituídas por células superficiais nucleadas e anucleadas e não há mais presença de neutrófilos, pois o espessamento do epitélio não permite a passagem dos (VANNUCCHI et al, 1997). Na vaginoscopia, a mucosa apresenta-se edemaciada, com coloração rosada que muda progressivamente até ficar esbranquiçada, com secreção serosanguinolenta na superfície e no aprofundamento, as dobras vaginais se tornam mais proeminentes em ambos os eixos, produzindo uma aparência de "calçada lisa" (JEFFCOATE; LINDSAY, 1989).

A cadela, no proestro, está sob influência estrogênica produzida e secretada pelas células da granulosa dos folículos ovarianos em desenvolvimento (FELDMAN; NELSON, 2004). $\mathrm{Na}$ fase folicular o centro tônico, localizado no hipotálamo, libera pequenas quantidades de hormônio liberador de gonadotrofinas $(\mathrm{GnRH})$ de forma pulsátil e com pequenas amplitudes, que irá estimular a liberação de FSH e LH no lobo anterior da hipófise, resultando no crescimento e desenvolvimento dos folículos ovarianos. Estes folículos apresentam uma dinâmica de crescimento, onde uma série de pequenos folículos antrais são recrutados e produzem de forma gradativa estrógeno e inibina. A inibina é responsável pela inibição da liberação de FSH pela hipófise. Quando a concentração de FSH chega a níveis basais, o recrutamento dos folículos se encerra. A liberação de estrógeno e inibina pelos folículos dominantes irão reduzir a quantidade de aporte venoso dos folículos, que entrarão em atresia. A concentração de estrógeno continua aumentando, assim como o tamanho do folículo, até atingir seu pico de máximo, e resultando feedback positivo da secreção de $\mathrm{GnRH}$, no centro pré ovulatório presente no hipotálamo, que por sua vez ira estimular o lobo anterior da hipófise a aumentar a produção de LH, culminando no pico pré ovulatório de LH (SENGER, 2005). 
A concentração sérica de estradiol aumenta de 5 para $15 \mathrm{pg} / \mathrm{ml}$ inicialmente, atingindo pico de $70 \mathrm{pg} / \mathrm{ml}$ entre 24 a 48 horas antes do início do estro. O declínio na concentração sérica de estrógeno desencadeia o estro, retornando a valores basais entre 5 a 20 dias, permanecendo neste patamar até a próxima fase folicular. A concentração de progesterona permanece com valores menores que $1 \mathrm{ng} / \mathrm{ml}$ durante todo o proestro. $O$ proestro geralmente termina com a aceitação da fêmea à monta após o pico de estradiol e endocrinologicamente termina com o pico pré ovulatório de LH (CONCANNON, 2011).

\subsubsection{Estro}

O estro tem uma duração variável de 4 a 24 dias, com média de 9 dias, e é caracterizado pela receptividade da fêmea ao macho, permitindo o coito (JOHNSTON; KUSTRITZ; OLSON, 2001). Sinais de estro, acompanham o declínio nos níveis de estrógeno e o aumento gradativo nas concentrações de progesterona (CONCANNON et al, 1989; CONCANNON, 2011; FELDMAN; NELSON, 2004). A vulva se torna flácida, e a secreção vaginal fica com uma coloração transparente a amarelo palha (FELDMAN; NELSON, 2004).

Não há alterações na citologia vaginal entre o pico de LH, a ovulação ou na hora da fertilização. Células superficiais e células escamosas anucleadas são predominantes, e não há presença de neutrófilos (VANNUCCHI et al, 1997). Na vaginoscopia, há uma redução da vascularização e do edema da mucosa vaginal e a superfície luminal da vagina se torna mais enrugada (ou "crenulada") (FELDMAN; NELSON, 2004).

A diminuição na concentração plasmática de estrógeno precede o pico de LH que ocorre no início do estro e conduz a ovulação. (JOHNSTON; KUSTRITZ; OLSON, 2001). Após o pico de LH, há um aumento na 
vascularização dos folículos dominantes controlada pela liberação de histamina e prostaglandina $\mathrm{E}_{2}\left(\mathrm{PGE}_{2}\right.$ ). A teca interna se torna edemaciada pelo aumento da permeabilidade vascular decorrente da liberação de histamina local, resultando no aumento da pressão hidrostática ao redor do folículo facilitando sua ruptura. As células da teca interna começam a produzir progesterona logo após o pico de LH. No início esta produção é apenas local, estimulando a produção de colagenase, responsável pela quebra do colágeno presente no tecido conjuntivo da túnica albugínea que reveste o ovário, além disso o fluido folicular presente dentro do folículo também aumenta sua produção, e ambos os eventos empurram e enfraquecem o ápice do folículo (denominado stigma). A PGE 2 e a prostaglandina $F_{2 \alpha}\left(P F_{2 \alpha}\right)$ secretadas localmente pelo ovário, são responsáveis pela contração dos músculos que compõem o ovário, aumentando a pressão local, forçando a protrusão do stigma até a superfície do ovário (SENGER, 2005). A ovulação ocorre em aproximadamente 2 a 3 dias após o pico de LH. Os oócitos são ovulados como oócitos primários e a fertilização só ocorrerá em 48 a 72 horas após a ovulação, quando se tornam oócitos secundários, onde sofrem a primeira divisão meiótica (JOHNSTON; KUSTRITZ; OLSON, 2001).

A concentração de estradiol continua a diminuir para valores basais (menores que $15 \mathrm{pg} / \mathrm{ml}$ ). E os valores de progesterona rapidamente aumentam de 0,5 a $1,0 \mathrm{ng} / \mathrm{ml}$ no final do proestro para 2 a $4 \mathrm{ng} / \mathrm{ml}, 24$ a 48 horas antes do pico de LH. E no momento da ovulação estes valores aumentam para 4 a 10 $\mathrm{ng} / \mathrm{ml}$. Nesta fase, a síntese e secreção de progesterona é realizada pelas células foliculares, antes do desenvolvimento do corpo lúteo (FELDMAN; NELSON, 2004). 


\subsubsection{Diestro}

O diestro é marcado pelo fim do período de cio, e, portanto, a fêmea não atrai mais o macho. Tem duração de aproximadamente 60 dias nas cadelas gestantes e de 60 a 100 dias nas cadelas não prenhes (RODRIGUES; RODRIGUES, 2002). O edema vulvar diminui progressivamente até retornar ao tamanho normal (FELDMAN; NELSON, 2004). O desenvolvimento das glândulas mamárias pode ocorrer em cadelas prenhas e não prenhas durante o diestro, pelo aumento na concentração de progesterona circulante. As cadelas prenhes secretam leite no fim da gestação e as cadelas não prenhes podem secretar leite no fim do diestro, e está associado à diminuição da concentração de progesterona e o aumento nos níveis de prolactina no final do diestro (JOHNSTON; KUSTRITZ; OLSON, 2001).

A citologia vaginal é representada por predomínio de células superficiais e escamosas anucleadas correspondendo a 80 a 100\% das células presentes no esfregaço e podem ou não estar acompanhadas de neutrófilos (VANNUCCHI et al, 1997).

Após a ovulação as células da teca interna e da granulosa começam a sofrer luteinização, sob a ação do LH (SENGER, 2005). O corpo lúteo será responsável pela produção de progesterona, e seus valores aumentam para 15 a $90 \mathrm{ng} / \mathrm{dl}$, de 20 a 30 dias após a ovulação (CONCANNON, 1989). Após este período, a concentração sérica de progesterona começa a diminuir gradativamente durante cinco a seis semanas. O corpo lúteo, aparentemente, é a única fonte de progesterona durante o diestro nas cadelas não prenhes e na gestação. A manutenção do corpo lúteo durante o diestro ainda não está bem definido (JOHNSTON; KUSTRITZ; OLSON, 2001). Alguns autores defendem que a secreção de LH e a prolactina são os responsáveis pela manutenção do corpo lúteo (CONCANNON, 1987), outros autores acreditam a prolactina é o fator luteotrófico na segunda metade do diestro, e não o LH (OKKENS et al, 1990). O corpo lúteo cessa sua função na cadela gestante em decorrência da 
produção de prostaglandinas pelo feto. $\mathrm{E}$ nas cadelas não gestantes este fenômeno ainda não está bem documentado (FELDMAN; NELSON, 2004). Durante a fase lútea, a progesterona promove e mantem o crescimento endometrial e a atividade glandular, suprime a atividade do miométrio e a função leucocitária intrauterina, fatores importantes para a manutenção da gestação, independente da presença de fetos.

\subsubsection{Anestro}

O anestro é o período de involução do útero após uma gestação ou pseudogestação. Possui duração variável, com média de 4,5 meses, porem o tempo pode oscilar, pois é difícil diferenciar o fim do diestro e o início do anestro em cadelas não prenhes (FELDMAN; NELSON, 2004). A transição da fase lútea para o anestro é gradativa, e o seu início pode ser definido quando a concentração de progesterona atinge a concentração menor que $3,0 \mathrm{nmol} / \mathrm{l}$ $(9,54 \mathrm{ng} / \mathrm{ml})$ (OKKENS; KOOISTRA, 2006).

Durante 0 anestro há o aumento da secreção pulsátil do hormônio liberador de gonadotrofina $(\mathrm{GnRH})$ pelo hipotálamo, resultando no aumento da sensibilidade da hipófise ao $\mathrm{GnRH}$ e dos ovários às gonadotrofinas. O FSH e o LH são liberados pelas células gonadotróficas da hipófise de forma pulsátil, sendo que a concentração de FSH no terço médio e final do anestro aumenta, estimulando a foliculogênese nos folículos ovarianos. Há também o aumento pulsátil do LH, nos dias que antecedem o início do proestro (OKKENS: KOOISTRA, 2006). 


\subsection{Hormônios}

Os hormônios esteroides são divididos em duas classes: os hormônios sexuais e progestacionais, sintetizados pelas gônadas (ovários e testículos) e os hormônios adrenocorticais, produzidos no córtex da adrenal. A estrutura química é baseada no núcleo ciclopentanoperidrofenantreno, sendo o colesterol $\left(\mathrm{C}_{27}\right)$ o precursor de todos os hormônios esteroidais. A biossíntese dos hormônios esteroidais é representada pela cascata da esteroidogênese, sendo as progestinas e os estrógenos, os principais hormônios esteroidais sexuais femininos. Os hormônios esteroides são transportados por proteínas plasmáticas e metabolizadas pelo fígado (DEVLIN, 2007).

\subsubsection{Estrógeno}

O estrógeno é um hormônio esteroide com 18 átomos de carbono $\left(\mathrm{C}_{18}\right)$, sendo representado pelo $17 \beta$-estradiol, produzido pelas células da teca e da granulosa do folículo ovariano (NORMAN; LITWACK, 1997). Durante o desenvolvimento folicular, o LH se liga a receptores de membrana localizados nas células da teca interna, esta ligação ativa a conversão do colesterol em testosterona, que se difunde para as células da granulosa. As células da granulosa possuem receptores de FSH e quando são ativadas, promovem a conversão da testosterona em estradiol (SENGER, 2005), mediante o processo de aromatização pelo complexo enzimático P-450 aromatase (SANGHA; SHARMA; GURAYA, 2002). 


\subsubsection{Progesterona}

A progesterona possui em sua estrutura 21 carbonos $\left(C_{21}\right)$. A conversão do colesterol em pregnenolona ocorre pela enzima P450scc, e segue duas vias, dando origem ao cortisol pela ação da 17a-hidroxilase e à progesterona sob ação da $3 \beta$-hidroxiesteroide-desidrogenase. A progesterona é sintetizada pelo corpo lúteo e pela placenta (NORMAN; LITWACK, 1997).

\subsection{Metodologia de Dosagem Hormonal}

\subsubsection{Radioimunoensaio (RIE)}

Em 1960, Solomon Berson e Rosalyn Yalow descreveram a técnica de mensuração de insulina plasmática por radioimunoensaio (RIE) aumentado o conhecimento da patologia dos diferentes tipos de diabetes (BLUMENTHAL, 2009). No mesmo período, em Londres, Roger Elkins também descreveu a técnica, e a denominou análise de saturação (THORELL; LARSON, 1978).

A técnica se baseia em uma quantidade fixa de hormônio radioativo que compete com o hormônio a ser mensurado, por um número limitado (saturado) de sítios de ligação de um agente ligante de alta afinidade e especificidade pelo hormônio em questão. A quantidade de hormônio radioativo que se liga é irreversivelmente proporcional a concentração do hormônio a ser mensurado (THORELL; LARSON, 1978; FURTADO, 2007).

Segundo Furtado (2007), para obtenção do material radioativo são necessárias licenças especiais junto aos órgãos reguladores, como a Comissão Nacional de Energia Nuclear (CNEN), e são gerados rejeitos 
radioativos que devem permanecer armazenados no laboratório por um período de aproximadamente 60 dias para o decaimento da meia vida do $\mathrm{I}^{125}$, e posterior descarte. A necessidade de instalações e equipamentos específicos para detecção e controle da radioatividade e a possibilidade de mensuração de apenas um metabolito por ensaio, aumenta o custo e o tempo de analise por amostra dosada. Porém, sua utilização na medicina veterinária, é amplamente difundido por ser um sistema aberto de dosagem, e, portanto, é de fácil validação e gera dados de elevada confiabilidade facilitando sua reprodutibilidade, sendo utilizada como teste de padrão ouro para dosagens hormonais. A dosagem de progesterona por radioimunoensaio pode ser realizada pela técnica em fase sólida, com ou sem extração, sendo ambas confiáveis para monitorar a função lútea em cadelas (SRIKANDAKUMAR et al, 1986).

\subsubsection{Luminex ${ }^{\circledR}$}

A citometria de fluxo foi desenvolvida há mais de 30 anos (VIGNALLI, 2000). E apesar da sua utilização ser baseada em células, partículas como microesferas também podem ser detectadas pela luz do laser (KELLAR; IANNONE, 2002). Em 1977, o citômetro de fluxo foi usado para detectar antígenos ligados a anticorpos presentes na superfície das microesferas (HORAN; WHEELESS, 1977), e desencadeou uma serie de experimentos, sendo o primeiro ensaio desenvolvido em 1982 para quantificação de $\mathrm{lgG}$ em humanos (LISI et al, 1982).

A empresa Luminex ${ }^{\circledR}$ desenvolveu o primeiro citômetro de fluxo designado especificamente para análise de múltiplas microesferas (beads) na década de 90. O Luminex ${ }^{\circledR}-100$ possui um sistema com detecção de três cores de fluorescência, sendo duas cores destinadas a classificação das beads e a 
terceira cor é usada para a mensuração da intensidade da fluorescência (KELLAR; IANNONE,2002). A tecnologia desenvolvida pela Luminex ${ }^{\oplus}$, foi denominada tecnologia XMAP (multiple analyte profile) ou ensaio Luminex ${ }^{\circledR}$, podendo ser denominada também como ensaio multiplex baseado em beads (bead-based multiplex assays - BBMAs) ou como ensaio com citômetro com matriz de beads (cytometric bead array assays - CBA) (CHRISTOPHERHENNINGS et al, 2013). A tecnologia se baseia na obtenção de ligantes (peptídeos, nucleotídeos, proteínas, anticorpos, receptores, polissacarídeos ou lipídeos) que se ligam a beads fluorescentes (de poliestireno com 5,6 $\mathrm{m}$ ou magnéticas de $6,2 \mu \mathrm{m}$ de diâmetro) que emitem tonalidades diferentes de vermelho pela intensidade emitida por dois ou três corantes fluorescentes, podendo ser criados até 100 conjuntos de microesferas com tons diferentes. Os ligantes se ligarão aos analítos específicos da amostra analisada, e se ligarão a um anticorpo de detecção biotinilado. O resultado final é amplificado através da incubação com o conjugado estreptavidina-ficoeritrina, que será quantificado pelo sinal fluorescente emitido (LUMINEX ${ }^{\circledR}$, 2013; MILLIPORE, 2013).

As vantagens desta técnica, quando comparadas aos outros imunoensaios, é a habilidade de avaliar um grande número de amostras e múltiplos analítos simultaneamente, otimizando os ensaios e reduzindo custos, com menor tempo de obtenção de resultados por placa, menor quantidade de amostra biológica, maior amplitude da faixa de dosagem e menor limite de detecção (LUMINEX ${ }^{\circledR}$, 2013). 


\section{OBJETIVOS}

O objetivo deste trabalho visa avaliar a concentração sérica de estrógeno e progesterona em cadelas durante o ciclo estral por método imunoensaio multianalito (Lumine ${ }^{\circledR} x M A P^{\circledR}$ ), visando avaliar a aplicabilidade fisiológica e comparar os resultados com os valores de referência já estabelecidos pelo radioimunoensaio. 


\section{HIPÓTESES:}

4.1. As tecnologias usadas para dosagem de estrógeno e progesterona confirmam o esperado para a fisiologia clássica

4.2. Para a dosagem de estrógeno, o método de RIE pode ser substituído pelo Luminex ${ }^{\circledR}$

4.3. Para a dosagem de progesterona, o método de RIE pode ser substituído pelo Luminex ${ }^{\circledR}$ 


\section{MATERIAL E MÉTODOS:}

\subsection{Animais}

As amostras séricas foram coletadas de 7 cadelas (animais $A$ a G) da raça Border Collie, com média de idade de 4,5 anos, sendo os animais $C$ e $E$ com 2 anos, $F$ com 4 anos, D com 5 anos, a A com 6 anos e as cadelas B e G com 7 anos. Os animais $\mathrm{E}$ e $\mathrm{F}$ eram nulíparas, a $\mathrm{B}$ era primípara e o restante era multípara. Todas residem no Canil espaço Ducão, localizado em Valinhos (São Paulo/SP). As cadelas foram mantidas em box individualizados, alimentadas com ração comercial super premium três vezes ao dia, e água ad libidumm. Ao primeiro sinal de sangramento (durante o proestro e estro) as amostras foram coletadas com intervalo de 48hs e após o termino do sangramento (diestro) as amostras foram coletadas semanalmente. Todas as cadelas apresentaram cio regular. A média de dias em proestro/estro foi de 8 dias (variando entre 2 a 16 dias). E no diestro a média acompanhada foi de 25 dias (variando entre 19 a 35 dias), porém o período de diestro não foi acompanhado até o fim do ciclo, pois o objetivo do experimento foi avaliar a variação hormonal entre as fases e não durante o ciclo todo.

Para padronização do ciclo, todas as cadelas foram alinhadas como sendo o D0, o ultimo dia antes da ovulação, e, portanto, foi considerado o último valor antes de $4 \mathrm{ng} / \mathrm{ml}$.

\subsection{Coleta das Amostras}

As amostras foram coletadas em tubos de coleta com gel ativador de coagulação (tubo Gel BD SST II Advance®), através da punção de veia cefálica, após antissepsia, utilizando seringas descartáveis (Seringa $5 \mathrm{ml}$ sem 
agulha bico Luer Lock $\mathrm{BD} \circledast$ ) e agulhas hipodérmicas (Agulha 25x6 $\mathrm{BD} \AA$ ), com a retirada de $4 \mathrm{~mL}$ de sangue total. Os tubos foram centrifugados (Centrifuga Hettich Zentrifugen Universal $320 \AA$ ) a $1500 \mathrm{~g}$ por 15 minutos e o soro obtido foi acondicionado em micro tubos de $1,5 \mathrm{ml}$ de polietileno (Microtubo tipo Eppendorf $($ ). Os tubos foram devidamente identificados e congelados em freezer a $-20^{\circ} \mathrm{C}$ até a etapa subsequente de dosagem hormonal.

\subsection{Dosagens Hormonais}

As dosagens hormonais por RIE foram realizadas no Laboratório de Dosagens Hormonais (LDH) do Departamento de Reprodução da FMVZ/USP em São Paulo/SP. E as dosagens por Luminex ${ }^{\circledR}$ foram realizadas no Laboratório da Merck-Millipore em Alphaville/SP.

\subsubsection{Analises Hormonais por Radioimunoensaio (RIE)}

A análise da progesterona foi realizada pelo método de radioimunoensaio, utilizando conjunto diagnóstico comercial em fase sólida, da empresa Immunotech $\AA$ (Beckman Coulter Company, Marsielle, France), segundo protocolo do fabricante, previamente validado por Lopes (2012). E a análise do estrógeno foi realizado pelo mesmo método, utilizando o conjunto diagnostico comercial ultra sensitive estradiol, em fase liquida da empresa Beckman Coulter (Marsielle, France), seguindo o protocolo instituído pelo fabricante, sendo validado posteriormente. 


\subsubsection{Analises Hormonais por Luminex ${ }^{\circledR}$}

A técnica de Imunoensaio Multianalito para dosagem de estrógeno e progesterona foi realizada pelo Lumine ${ }^{\circledR} \mathrm{xMAP}^{\circledR}$, com o kit Multi Species Steroid/Thyroid Hormone (STTHMAG-21K; Millipore, Billerica, MA), seguindo o protocolo do fabricante. Segundo o fabricante, as amostras tiveram que ser extraídas antes da dosagem hormonal e optou-se por realizar a extração pelo método com acetonitrila, técnica também descrita no protocolo.

\subsection{Analise dos Resultados}

Para as análises estatísticas e os gráficos foram utilizados o Excel (@) Microsoft) e o Statview 5.1 (@ SAS, Inc). 


\section{RESULTADOS E DISCUSSÕES}

\subsection{Parâmetros de qualidade dos ensaios hormonais}

O controle de qualidade da progesterona e do estradiol pelo método de RIE foi realizado pela análise dos coeficientes de variação (CV) inter e intra ensaios. No ensaio da progesterona, os valores de CV foram menores que $5 \%$ e a sensibilidade mínima detectada foi de $0,002 \mathrm{ng} / \mathrm{ml}$ e $0,006 \mathrm{ng} / \mathrm{ml}$ nos dois ensaios, conforme demonstra a tabela 1. No ensaio de estradiol, os coeficientes de variação de inter-ensaio e intra-ensaio foram inferiores a $8 \%$, sendo a sensibilidade mínima detectada de $1,45 \mathrm{pg} / \mathrm{ml}$ e 1,98 pg/ml (tabela 2).

Tabela 1 - Controle de qualidade da Progesterona Sérica (Immunotech®)

\begin{tabular}{|c|c|c|c|c|c|c|}
\hline Ensaio & $\begin{array}{l}\text { CPM } \\
\text { total }\end{array}$ & $\begin{array}{l}\text { Cap. Lig. } \\
\text { B/B0 }\end{array}$ & $\begin{array}{l}\text { L.N.E. } \\
(\%)\end{array}$ & $\begin{array}{l}\text { Sensibilidade } \\
\%(\text { dose } \mathrm{ng} / \mathrm{ml} \text { ) }\end{array}$ & $\begin{array}{l}\text { CV Intra } \\
\text { Baixo }\end{array}$ & $\begin{array}{c}\text { CV Intra } \\
\text { Alto }\end{array}$ \\
\hline 1 & 44639 & $49 \%$ & $0,05 \%$ & $96(0,006)$ & $2,60 \%$ & $2,22 \%$ \\
\hline 2 & 44427 & $50 \%$ & $0,05 \%$ & $95(0,002)$ & $4,18 \%$ & $3,58 \%$ \\
\hline CV Inter ensaio & & & & & $0,72 \%$ & $0,82 \%$ \\
\hline
\end{tabular}

Legenda:

CPM: Contagem por minuto

Cap. Lig.: Capacidade de Ligação

L.N.E.: Ligação não específica

CV Intra: Coeficiente de variação intra-ensaio

CV Inter: Coeficiente de variação inter-ensaio 
Tabela 2 - Controle de qualidade do Estradiol Ultra Sensível (Immunotech®)

\begin{tabular}{|c|c|c|c|c|c|c|}
\hline Ensaio & $\begin{array}{l}\text { CPM } \\
\text { total }\end{array}$ & $\begin{array}{l}\text { Cap. Lig. } \\
\text { B/BO }\end{array}$ & $\begin{array}{l}\text { L.N.E. } \\
(\%)\end{array}$ & $\begin{array}{l}\text { Sensibilidade } \\
\%(\text { dose } \mathrm{ng} / \mathrm{ml})\end{array}$ & $\begin{array}{c}\text { CV Intra } \\
\text { Baixo }\end{array}$ & $\begin{array}{l}\text { CV Intra } \\
\text { Alto }\end{array}$ \\
\hline 1 & 40083 & $52 \%$ & $0,63 \%$ & $95(1,45)$ & $4,74 \%$ & $7,19 \%$ \\
\hline 2 & 46196 & $49 \%$ & $0,34 \%$ & $91(1,98)$ & $1,42 \%$ & $3,20 \%$ \\
\hline CV Inter ensaio & & & & & $1,72 \%$ & $1,86 \%$ \\
\hline \multicolumn{7}{|c|}{$\begin{array}{l}\text { Legenda: } \\
\text { CPM: Contagem por minuto } \\
\text { Cap. Lig.: Capacidade de Ligação } \\
\text { L.N.E.: Ligação não específica } \\
\text { CV Intra: Coeficiente de variação intra-ensaio } \\
\text { CV Inter: Coeficiente de variação inter-ensaio }\end{array}$} \\
\hline \multicolumn{7}{|c|}{$\begin{array}{l}\text { Para o Luminex }{ }^{\circledR} \text {, o controle de qualidade foi avaliado pela sensibilidade da } \\
\text { gesterona de } 91,09 \% \text {, com valor mínimo detectado de } 0,04 \mathrm{ng} / \mathrm{ml} \text { e o } \\
\text { tradiol teve sensibilidade de } 94,27 \% \text {, sendo } 0,0049 \mathrm{ng} / \mathrm{ml} \text { o menor valor } \\
\text { tectado. O CV geral do estradiol foi de } 2,42 \text { e o da progesterona foi de } 0,18 \text {. }\end{array}$} \\
\hline
\end{tabular}

\subsection{Validação laboratorial do Kit Comercial Ultra Sensitive Estradiol por radioimmunoensaio (Immunotech ${ }^{\circledR}$ )}

A validação laboratorial foi realizada por paralelismo utilizando matriz integra, para avaliar se o material utilizado interferiu na ligação antígenoanticorpo. Para isso foi utilizado um "pool" de amostras de cães com concentração de estradiol $<2,54 \mathrm{pg} / \mathrm{ml}$. A esta amostra foi adicionada uma concentração conhecida do padrão do estradiol, a fim de aproxima-lo do ponto máximo da curva padrão fornecida pelo conjunto diagnostico $(3.000 \mathrm{pg} / \mathrm{ml})$. Após esta etapa foi realizado diluições seriadas (com o uso da própria matriz íntegra) para construção de uma curva com valores aproximados com a curva fornecida pelo kit (3000,0; 1500,0; 300,0; 100,0; 30,0 e 10,0 pg/ml). 
O resultado obtido para verificação de paralelismo no método empregado está representado nos gráficos abaixo ( $R$ squared $=0,962, p<0,0001)$.

Gráfico 1 - Representação gráfica da curva de paralelismo obtida para estradiol utilizando matriz sérica.

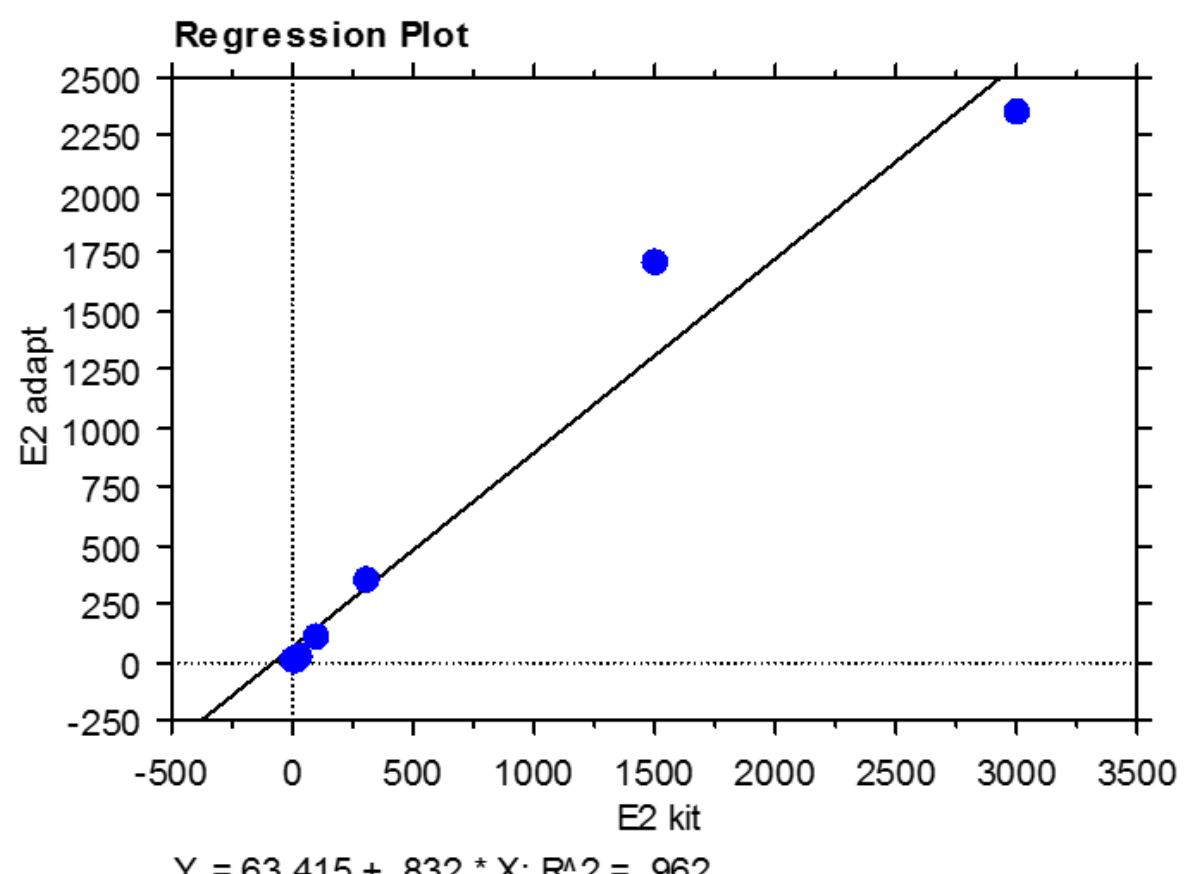

O uso de radioimunoensaio para dosagem de estradiol já foi descrito em diversos trabalhos (INABA, et al, 1988; ONCLIN, MURPHY, VERSTEGEN, 2002; DE GIER et al, 2006; ROTA et al, 2007). Porem a técnica empregada não foi descrita em nenhum deles, havendo, portanto, a necessidade da validação do conjunto comercial utilizado neste experimento.

\subsection{Perfil da Progesterona por RIE e Luminex ${ }^{\circledR}$}

Os resultados obtidos nas dosagens séricas de progesterona por RIE, estão demonstrados no Gráfico 2. Segundo Feldman e Nelson (2004), valores entre 4 e $10 \mathrm{ng} / \mathrm{ml}$, representam o momento da ovulação. Como o objetivo do trabalho não foi avaliar o momento da ovulação e sim as flutuações hormonais, para a padronização do ciclo, todas as cadelas foram alinhadas como sendo o D0, o 
ultimo dia antes da ovulação, e, portanto, foi considerado o último valor antes de $4 \mathrm{ng} / \mathrm{ml}$. A concentração média da progesterona por RIE, na fase de proestro/estro foi de $0,78 \mathrm{ng} / \mathrm{ml}$, com erro padrão da média ( $\pm E P M$ ) de $\pm 0,17$, sendo o valor mínimo de $0,20 \mathrm{ng} / \mathrm{ml}$ e valor máximo de $3,93 \mathrm{ng} / \mathrm{ml}$, e na fase de diestro a média foi de $19,48 \mathrm{ng} / \mathrm{ml}( \pm 1,40)$, com variação de 4,01 a $38,18 \mathrm{ng} / \mathrm{ml}$, representados na tabela 3. Estes valores estão de acordo com Feldman e Nelson (2004), uma vez que o proestro/estro é caracterizado com valores de progesterona menores que $1 \mathrm{ng} / \mathrm{ml}$ a $4 \mathrm{ng} / \mathrm{ml}$ e no diestro estes valores aumentam para 15 a $90 \mathrm{ng} / \mathrm{ml}$. Concannon (2011) caracteriza o estro com valores de progesterona entre 1 a $3 \mathrm{ng} / \mathrm{ml}$, durante a onda pré ovulatória de $\mathrm{LH}$, e o diestro com valores entre $15 \mathrm{a} 80 \mathrm{ng} / \mathrm{ml}$.

Gráfico 2 - Representação gráfica das concentrações séricas de progesterona por RIE obtidas durante o período de proestro/estro e diestro dos animais A-G.

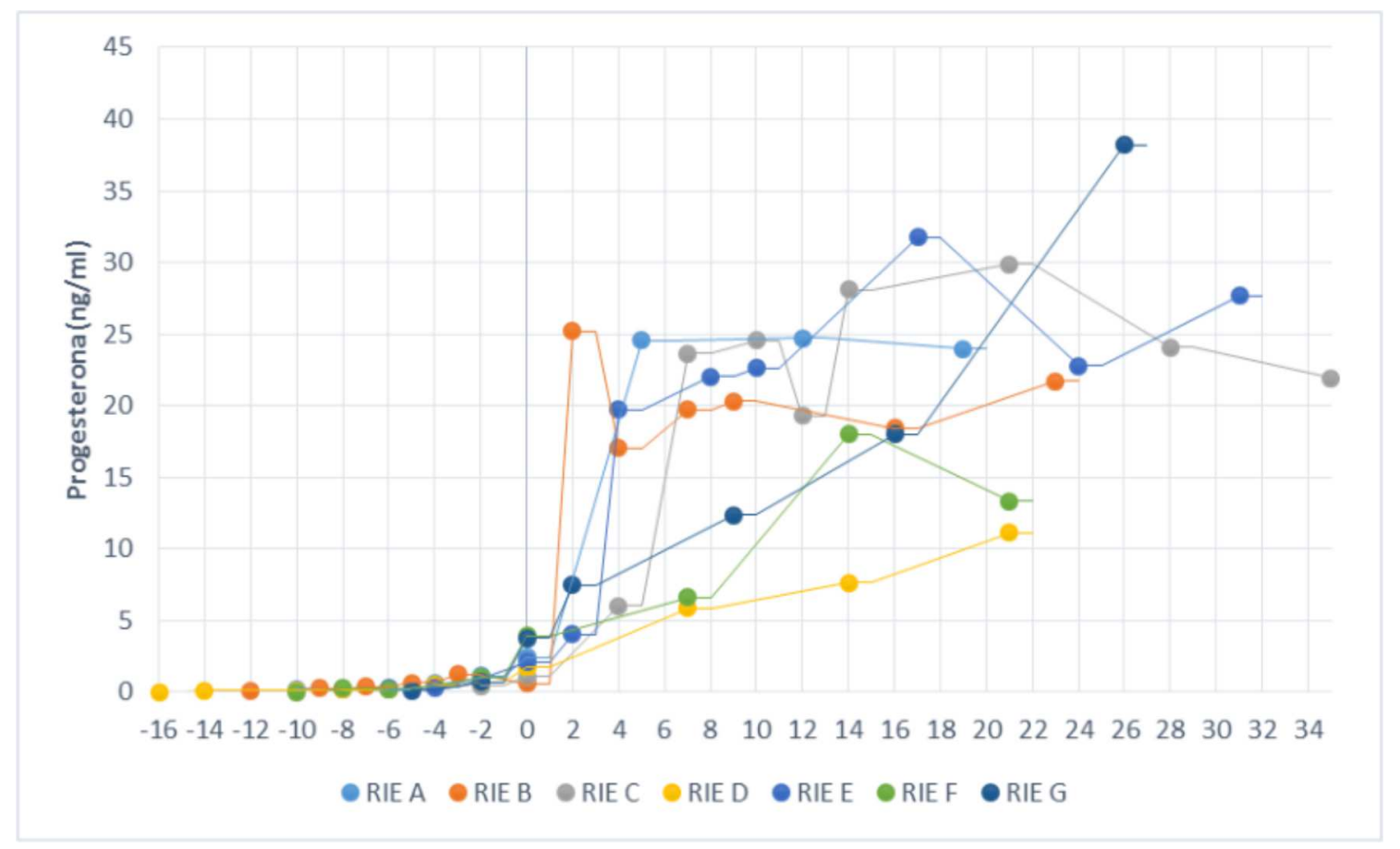

Quando analisamos as dosagens de progesterona nos animais individualmente, notamos que os animais B e C apresentaram período de sangramento prolongado (proestro/estro), e ao realizar dosagem hormonal as concentrações de progesterona eram compatíveis com o período de diestro. $\mathrm{O}$ gráfico 3 representa as flutuações de progesterona destes animais, e as setas indicam o início e o fim do sangramento vaginal. 
Gráfico 3 - Representação gráfica das concentrações séricas de progesterona por RIE dos animais $\mathrm{B}$ e $\mathrm{C}$, com sangramento vaginal prolongado.

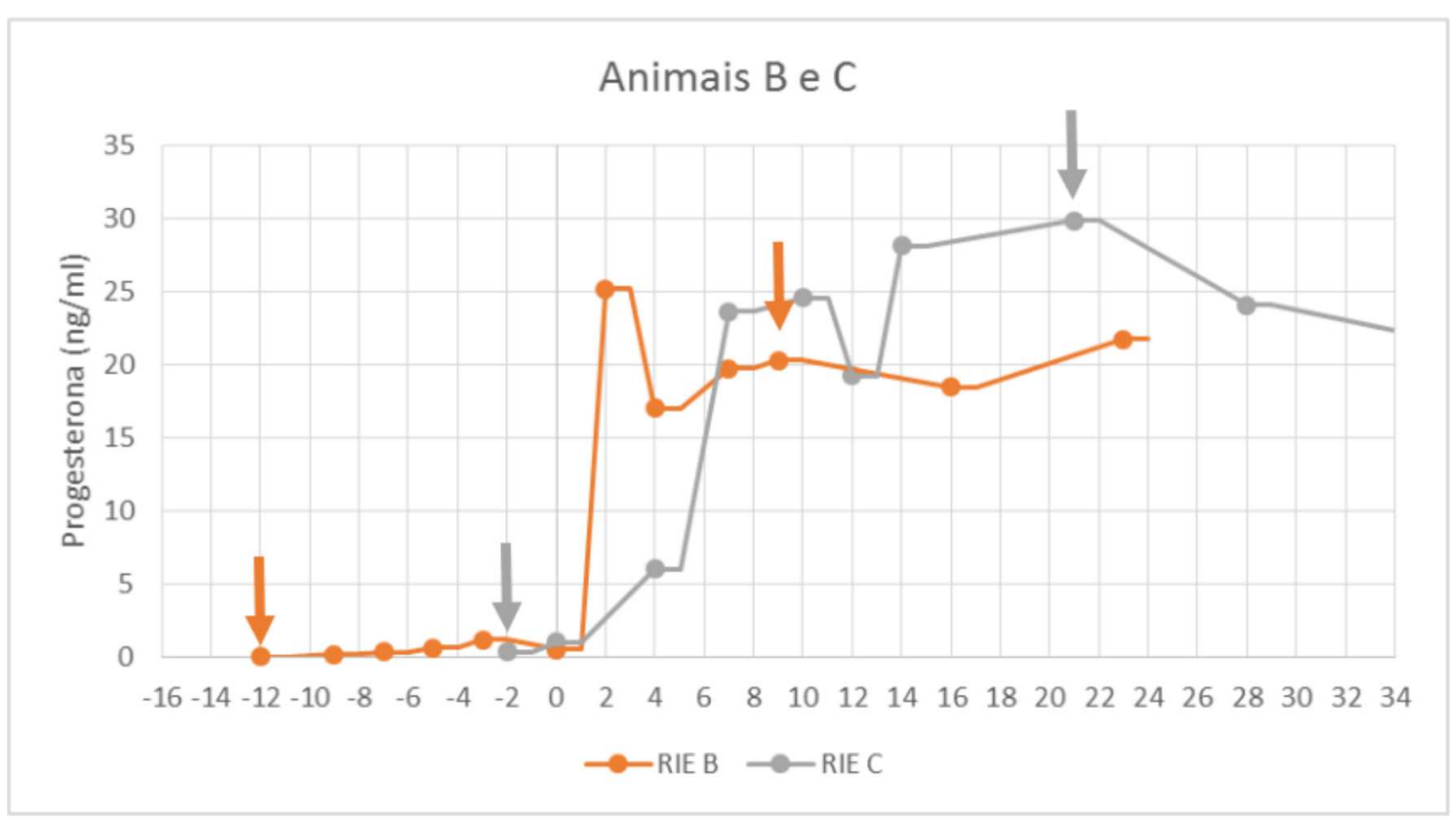

O animal D apresentou valores de progesterona, após o fim do sangramento, ainda dentro dos valores de referencia para o fim do estro (2 a 4 $\mathrm{ng} / \mathrm{ml}$ ), conforme demonstra o gráfico 4 . Neste animal a ovulação pode ter ocorrido tardiamente, uma vez que os valores de 4 a $10 \mathrm{ng} / \mathrm{ml}$ representam o periodo de ovulação, segundo Nelson e Feldman (2006). 
Gráfico 4 - Representação gráfica da concentração sérica de progesterona por RIE do animal D

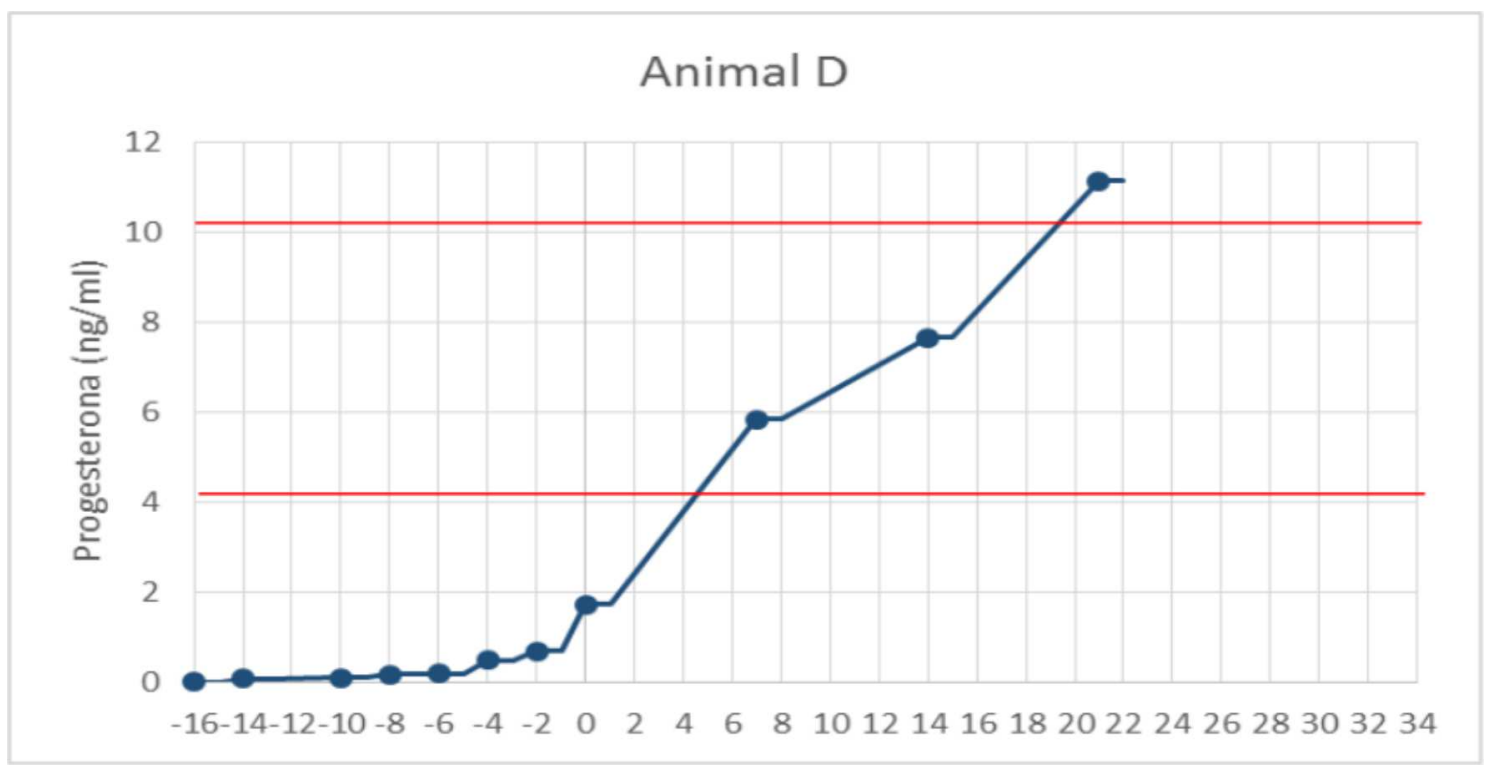

Os resultados obtidos das concentrações séricas de progesterona por Lumine ${ }^{\circledR}$ estão representados no gráfico 5. A média dos valores de progesterona durante o periodo de proestro/estro foi de $1,88 \mathrm{ng} / \mathrm{ml}( \pm 0,54)$, com variação de 0,4 a $12,99 \mathrm{ng} / \mathrm{ml}$ e apresentou média de $50,46 \mathrm{ng} / \mathrm{ml}( \pm 4,90)$ durante o periodo de diestro, com variação de 8,74 a $125,01 \mathrm{ng} / \mathrm{ml}$, representados na tabela 3 . Houve correlação entre os valores de progesterona na fase de proestro/estro $(p=0,001)$, porem não houve correlação significativa na fase de diestro $(p=0,41)$. A média dos valores sericos de progesterona no método Lumine ${ }^{\circledR}$ apresentaram diferença significativa, quando comparados ao método padrão de radioimunoensaio, tanto para a fase de proestro/estro $(p<0,01)$, quanto para a fase de diestro $(p<0,0001)$. A este fator, pode ser atribuido o fato do protocolo do kit Lumine ${ }^{\circledR}$, exigir a extração prévia das amostras a serem dosadas. Este processo de extração permite a concentração da fração proteica do soro/plasma, aumentado assim a quantidade das mesmas na solução, otimizando o ensaio. 
Gráfico 5 - Representação gráfica das concentrações séricas de progesterona por Luminex® obtidas durante o período de proestro/estro e diestro dos animais A-G.

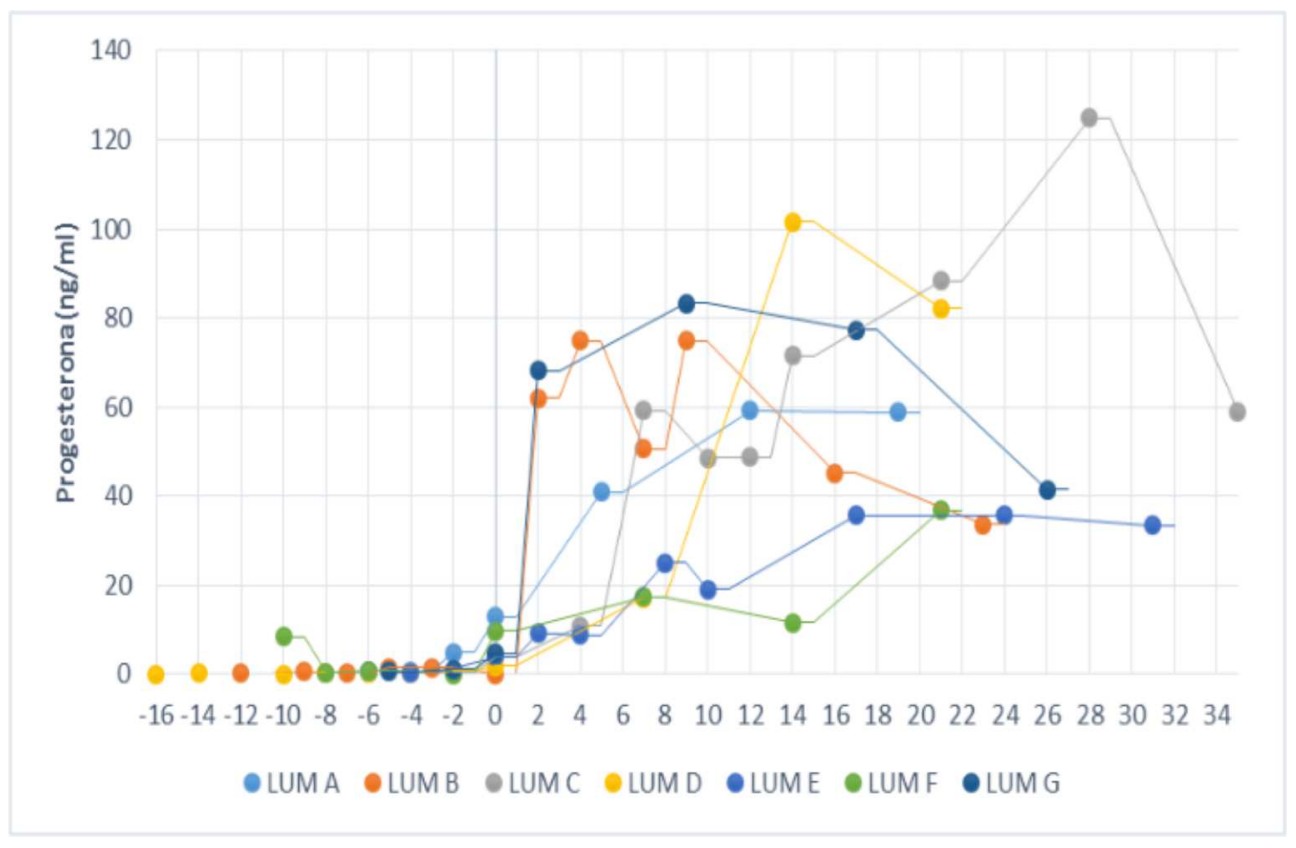

Tabela 3 - Médias dos valores séricos ( \pm EPM) de progesterona por RIE e LUM nas fases de proestro/estro e diestro.

\begin{tabular}{lccccc}
\hline & P4 RIE $(\mathrm{ng} / \mathrm{ml})$ & \pm EPM & P4 LUM (ng/ml) & \pm EPM & Correlação $\mathrm{r}(\mathrm{p})$ \\
\hline Fase Proestro/Estro & $0,78^{\mathrm{a}}$ & $\pm 0,17$ & $1,88^{\mathrm{b}}$ & $\pm 0,54$ & $0,68(0,001)$ \\
Fase Diestro & $19,48^{\mathrm{a}}$ & $\pm 1,40$ & $50,46^{\mathrm{b}}$ & $\pm 4,90$ & $0,15(0,41)$ \\
\hline
\end{tabular}

ab Letras minúsculas diferentes dentro da mesma linha é igual a médias estatisticamente diferentes $(p<0,05)$

O gráfico 6 representa as médias dos valores de progesterona por radioimunoensaio e pelo método Luminex ${ }^{\circledR}$. Em ambas as metodologias é possivel diferenciar a fase de proestro/estro (D-16 a D0) da fase de diestro (D0 a D34). Quando analisadas separadamente (graficos 7 e 8) é possivel identificar que há uma equivalencia de valores entre as metodologias. No grafico 7, a linha, marca o valor médio de D0, estabelecido como o dia que antecede a ovulação, de $2,2 \mathrm{ng} / \mathrm{ml}( \pm 0,48)$. Se delimitarmos a mesma linha para o grafico 8, o valor médio do D0 no Luminex ${ }^{\circledR}$ seria de $5,3 \mathrm{ng} / \mathrm{ml}( \pm 1,70)$, o que confirma a analise estatistiva das médias, justificando que os valores de progesterona pelo Luminex ${ }^{\circledR}$ são maiores que os valores por radioimunoensaio, e que possivelmente, os valores de referencia utilizados para 0 radioimunoensaio não são equivalentes para $\circ$ Luminex ${ }^{\circledR}$, havendo a 
necessidade de se estalebeler novos valores de referencia para esta metodologia. No grafico 9 é possivel verificar a diferença estatistica entre as fases de proestro/estro e diestro.

Gráfico 6 - Representação gráfica das médias ( $\pm E P M)$ dos valores de progesterona por RIE e LUM.

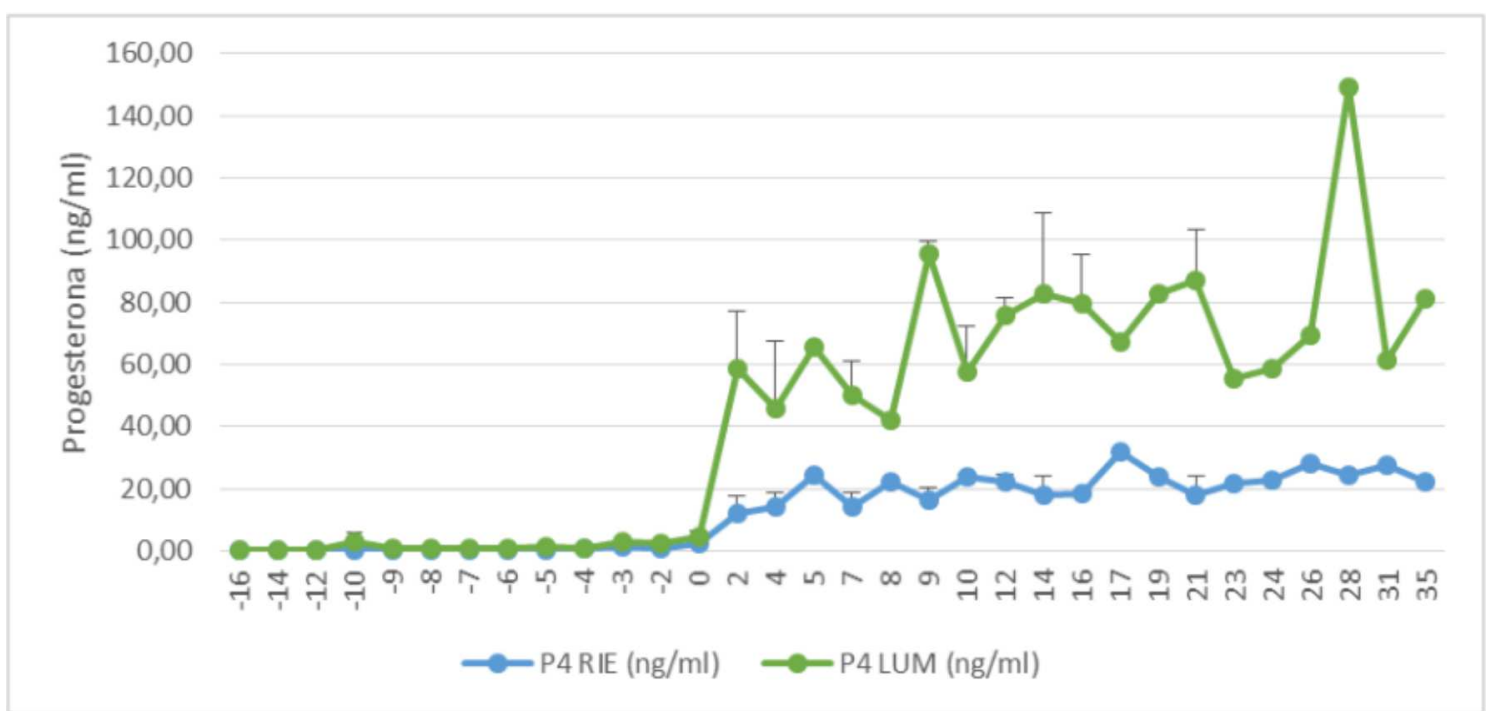

Gráfico 7 - Representação gráfica das médias (士EPM) dos valores de progesterona por RIE. A linha demarca o valor médio no D0.

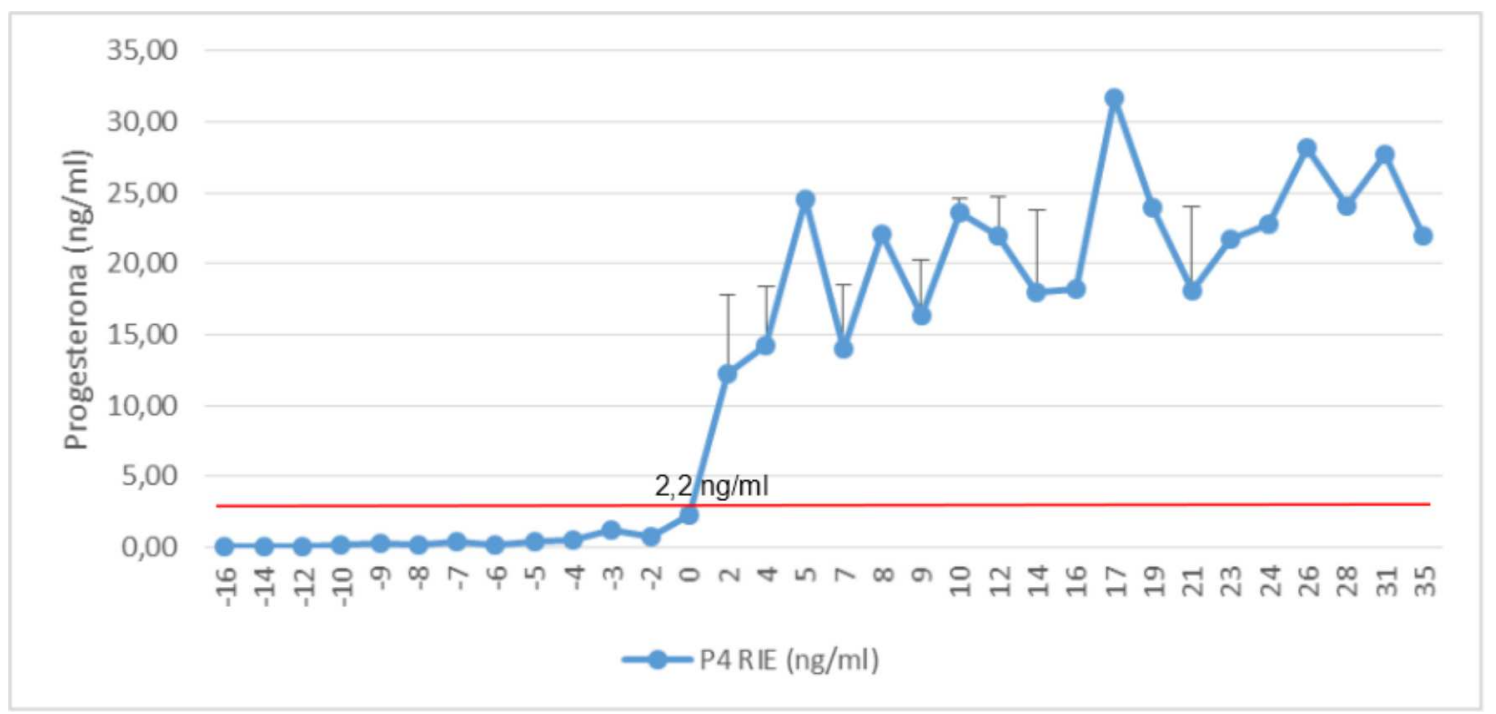


Gráfico 8 -Representação gráfica das médias ( \pm EPM) dos valores de progesterona por Luminex®. A linha demarca o valor médio no D0.

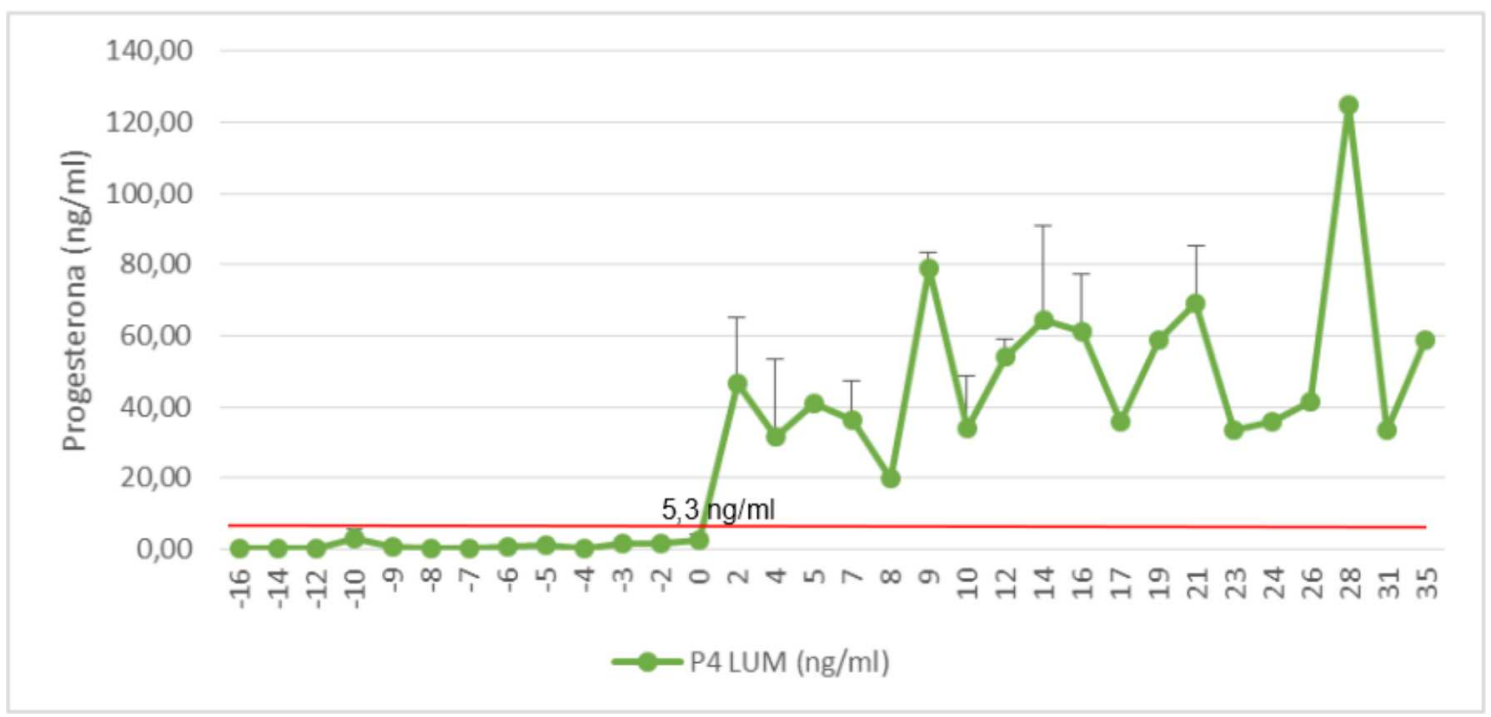

Gráfico 9 - Representação grafica dos valores médios ( $\pm E P M)$ de progesterona dosado por radioimunoensaio e Luminex®, nas fases de proestro/estro e na fase de diestro.

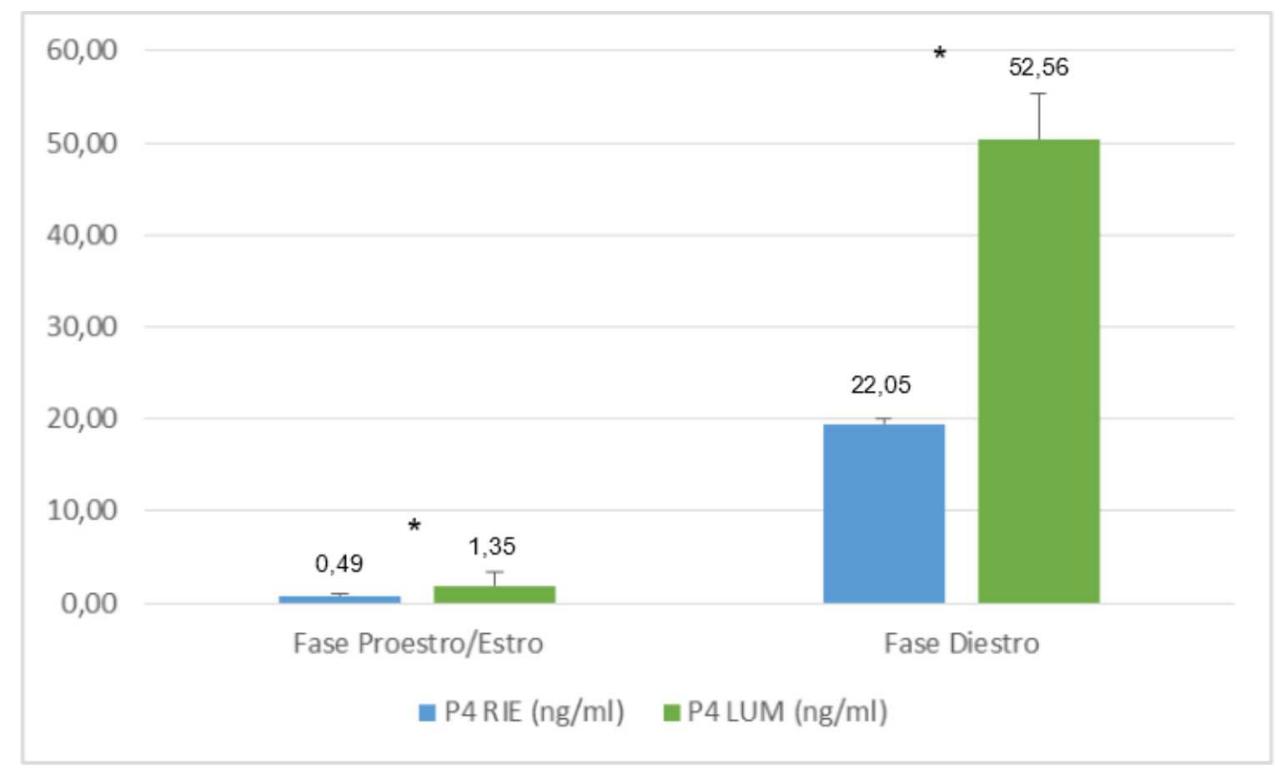

* Diferença significativa entre as médias de progesterona na fase de proestro/estro e diestro 


\subsection{Correlação entre Progesterona por RIE e Luminex ${ }^{\circledR}$}

Para análise de correlação da progesterona, incialmente foram realizados os testes de Bartlett e Kolmogorov-Smirnov, os quais confirmara haver, tanto homogeneidade de variância quanto compatibilidade de distribuição normal, tendo-se optado, portanto pela análise de correlação por meio do coeficiente de correlação de Pearson que foi positiva $(r=0,7)$ entre a progesterona dosada pelo RIE e pelo Luminex ${ }^{\circledR}$, sendo $p<0,0001$, representado pelo gráfico 10.

Gráfico 10 - Representação gráfica da correlação de Pearson obtida entre a progesterona dosada pelo RIE e pelo Luminex®.

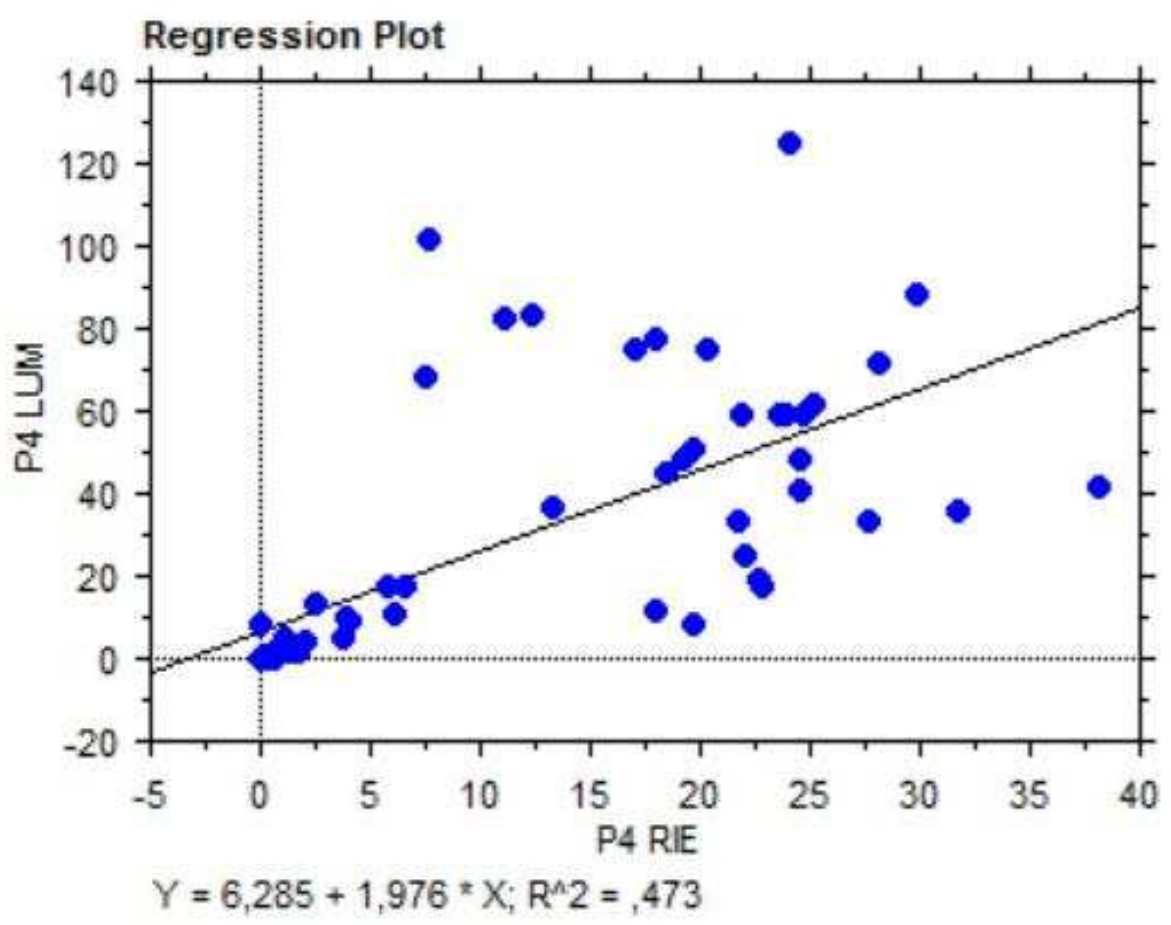

Ao analisarmos a progesterona durante as duas fases distintas observadas proestro/estro e diestro, houve uma correlação positiva entre os dois métodos $(r=0,68, p<0,0001)$ durante a fase de proestro/estro (Gráfico 11) e não houve correlação durante a fase de diestro $(r=0,15, p=0,41)$, representado no gráfico 12. 
Gráfico 11 -- Representação gráfica da correlação positiva entre o RIE e o LUM durante a fase de proestro/estro na dosagem de progesterona

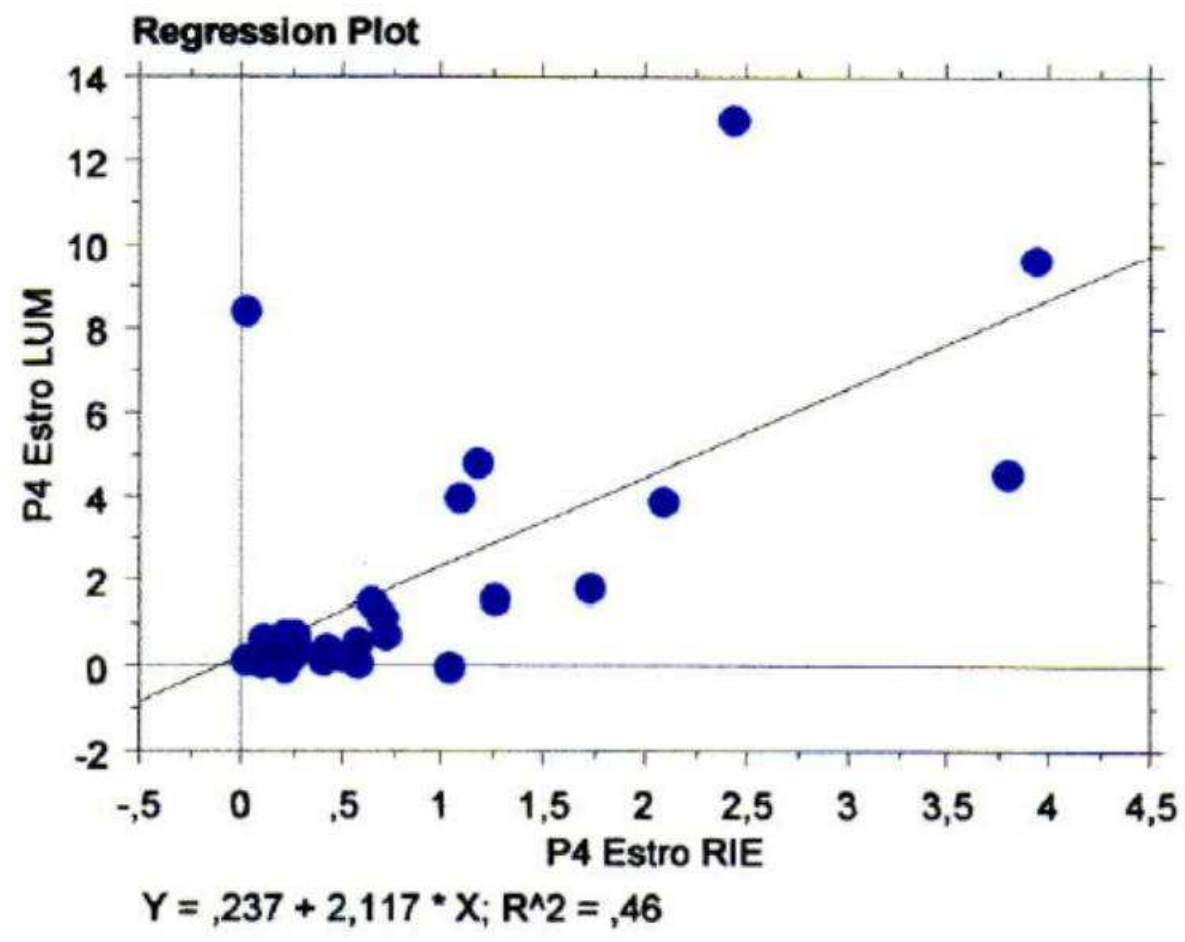

Gráfico 12 - Representação gráfica da ausência de correlação entre o RIE e LUM durante o diestro na dosagem de progesterona.

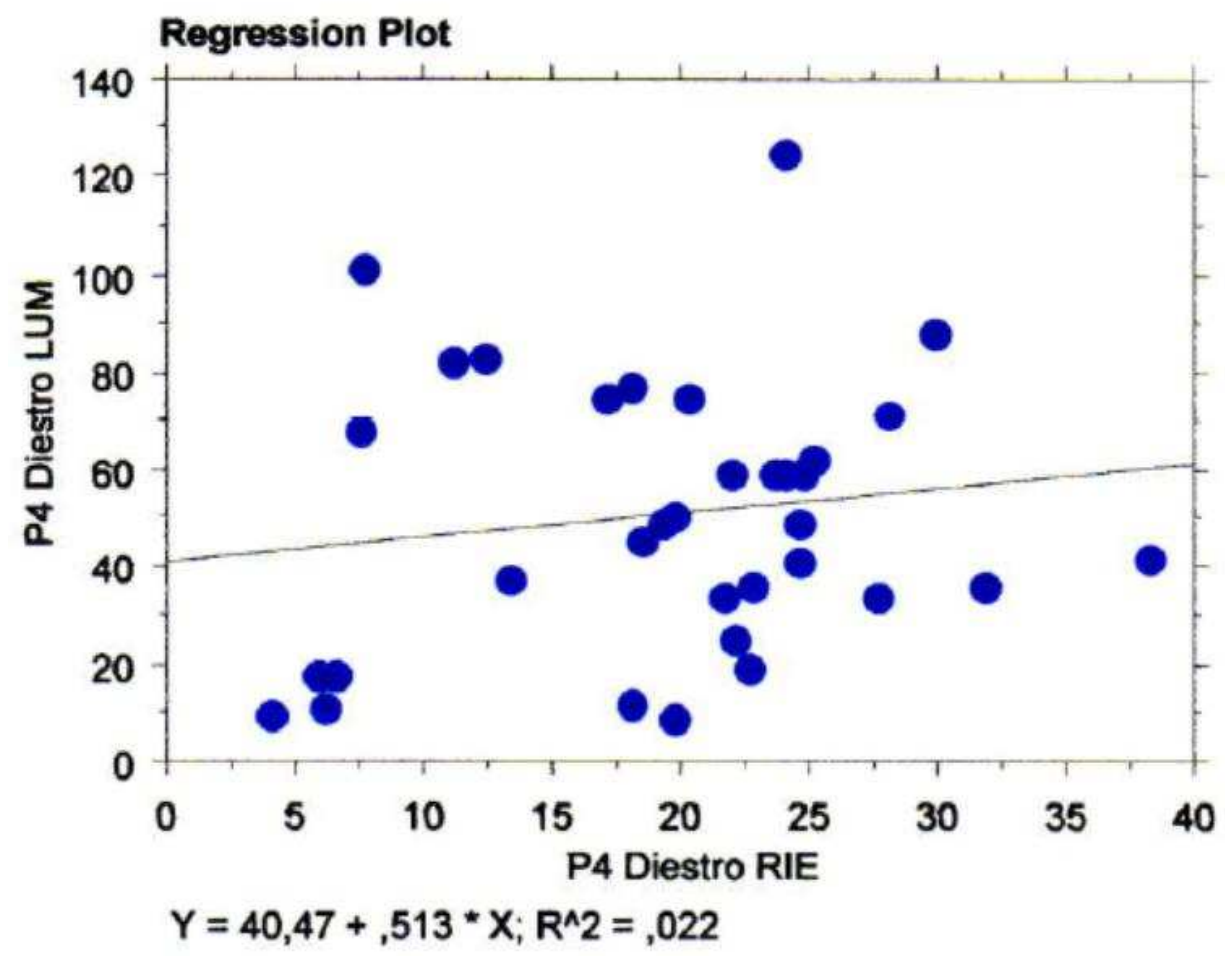




\subsection{Perfil do Estradiol por RIE e Luminex ${ }^{\circledR}$}

O grafico 13 representa as médias ( \pm EPM) dos valores de estradiol mensurados por RIE. O grafico apresenta uma flutuação variavel nos valores de estradiol, não possibilitando a diferenciação das fases de proestro/estro, onde os valores deveriam ser mais elevados, uma vez que o estradiol aumenta de 5 a $15 \mathrm{pg} / \mathrm{ml}$, atingindo pico de $70 \mathrm{pg} / \mathrm{ml}$ antes do inicio do estro (CONCANNON, 2011) e após a ovulação, estes valores apresentariam uma uma diminuição para niveis basais (menores que $15 \mathrm{pg} / \mathrm{ml}$ ), que se manterão até a proxima fase folicular (CONCANNON, 2011). A média dos valores de estradiol na fase de proestro/estro foi de $20,01 \mathrm{pg} / \mathrm{ml}( \pm 2,54)$, com valor minimo de $1,45 \mathrm{ng} / \mathrm{ml}$ e máximo de $68,10 \mathrm{ng} / \mathrm{ml}$ e a média foi de $23,85 \mathrm{pg} / \mathrm{ml}( \pm 2,40)$ na fase caracterizada pelo diestro, com valores variando entre 9,60 a 61,01 pg/ml, representados na tabela 4 .

Gráfico 13 - Representação gráfica das médias (士EPM) dos valores de estradiol por radioimunoensaio.

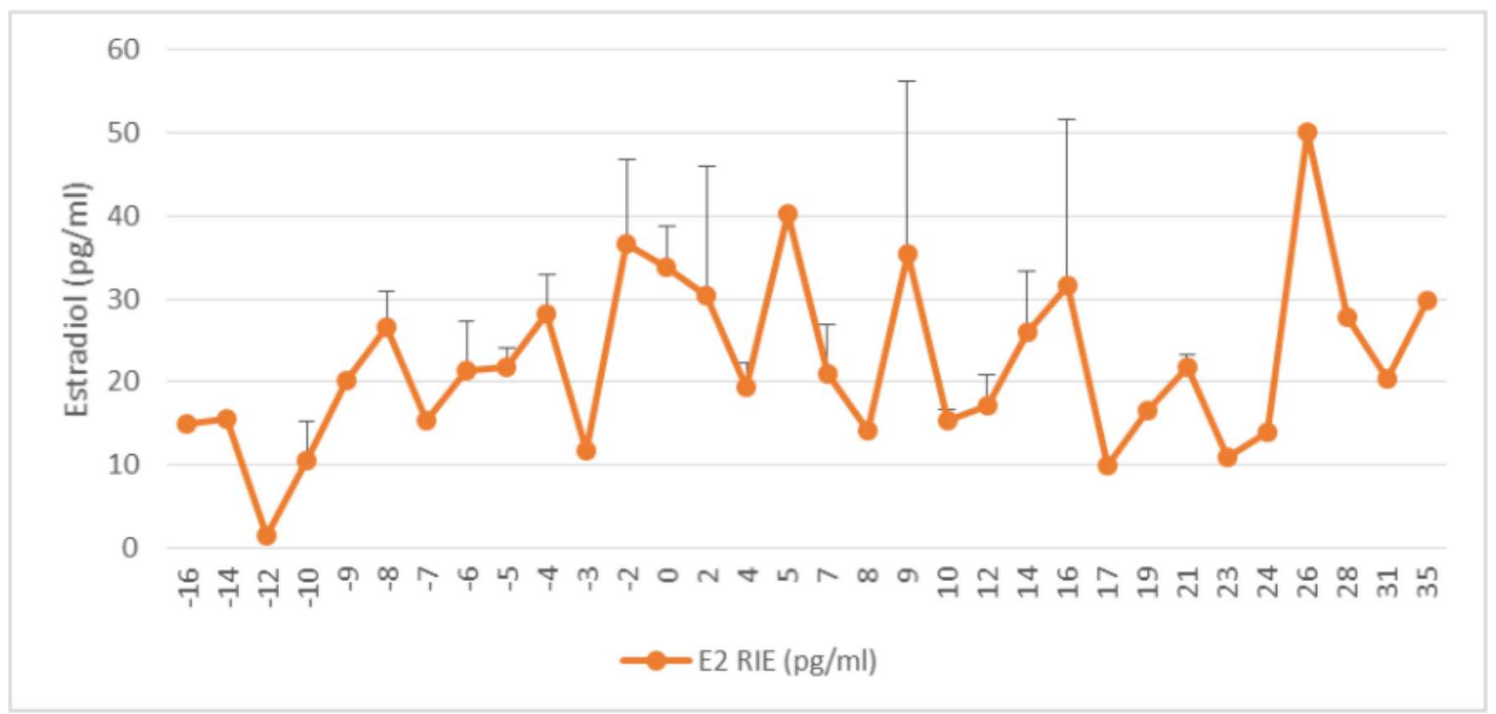

Tabela 4 - Médias dos valores séricos (士EPM) de estradiol por RIE e LUM nas fases de proestro/estro e diestro.

\begin{tabular}{lccccc}
\hline & E2 RIE $(\mathrm{pg} / \mathrm{ml})$ & \pm EPM & E2 LUM $(\mathrm{pg} / \mathrm{ml})$ & \pm EPM & Correlação $\mathrm{r}(\mathrm{p})$ \\
\hline Fase Proestro/Estro & $25,01^{\mathrm{a}}$ & $\pm 2,54$ & $362,00^{\mathrm{b}}$ & $\pm 8,30$ & $0,09(0,63)$ \\
Fase Diestro & $23,85^{\mathrm{a}}$ & $\pm 2,40$ & $102,65^{\mathrm{b}}$ & $\pm 14,86$ & $0,04(0,81)$ \\
\hline ab Letras minúsculas diferentes dentro da mesma linha é igual a médias estatisticamente \\
diferentes $(\mathrm{p}<0,05)$
\end{tabular}


As médias dos valores de estradiol obtidos pelo Lumine $^{\circledR}$, estão representados no grafico 14 , sendo na fase de proestro/estro a media de $362,00 \mathrm{pg} / \mathrm{ml}( \pm 8,30)$, variando entre 100,00 a $2.340,00 \mathrm{pg} / \mathrm{ml}$ e média de $102,65 \mathrm{pg} / \mathrm{ml}( \pm 14,86)$ para a fase de diestro, com valor mínimo de $10,00 \mathrm{pg} / \mathrm{ml}$ e máximo de $330,00 \mathrm{pg} / \mathrm{ml}$. Não Houve correlação positiva entre as duas metodologias $(r=0,09$ e $p=0,63$ na fase de proestro/estro e $r=0,04$ e $p=0,81$ na fase de diestro), porem as médias apresentaram diferença significativa nas duas fases $(p<0,003$ na fase de proestro/estro e $p<0,0001)$. Mesmo não havendo uma correlação significativa, é possivel identificar uma tendência à diminuição do estradiol após o D0, que vai ao encontro com o descrito na literatura, sendo mais representativo no Lumine ${ }^{\circledR}$ do que no radioimunoensaio, possivelmente pela necessidade de extração das amostras nesta metodologia. O ponto D-3 pode ser considerado um ponto outlier, pois é um valor correspondente a apenas um valor de um animal, não representando a média do dia em questão. As médias dos valores obtidos pelo Lumine ${ }^{\circledR}$ foram estatisticamente significantes, o foram superiores aos valores obtidos pelo RIE, necessitando de um valor de referencia diferenciado para a metodologia testada. No grafico 15 é possivel verificar a diferença significativa das médias globais do estradiol nas fases de proestro/estro e no diestro.

Gráfico 14 - Representação gráfica das médias (土EPM) dos valores de estradiol por Luminex®

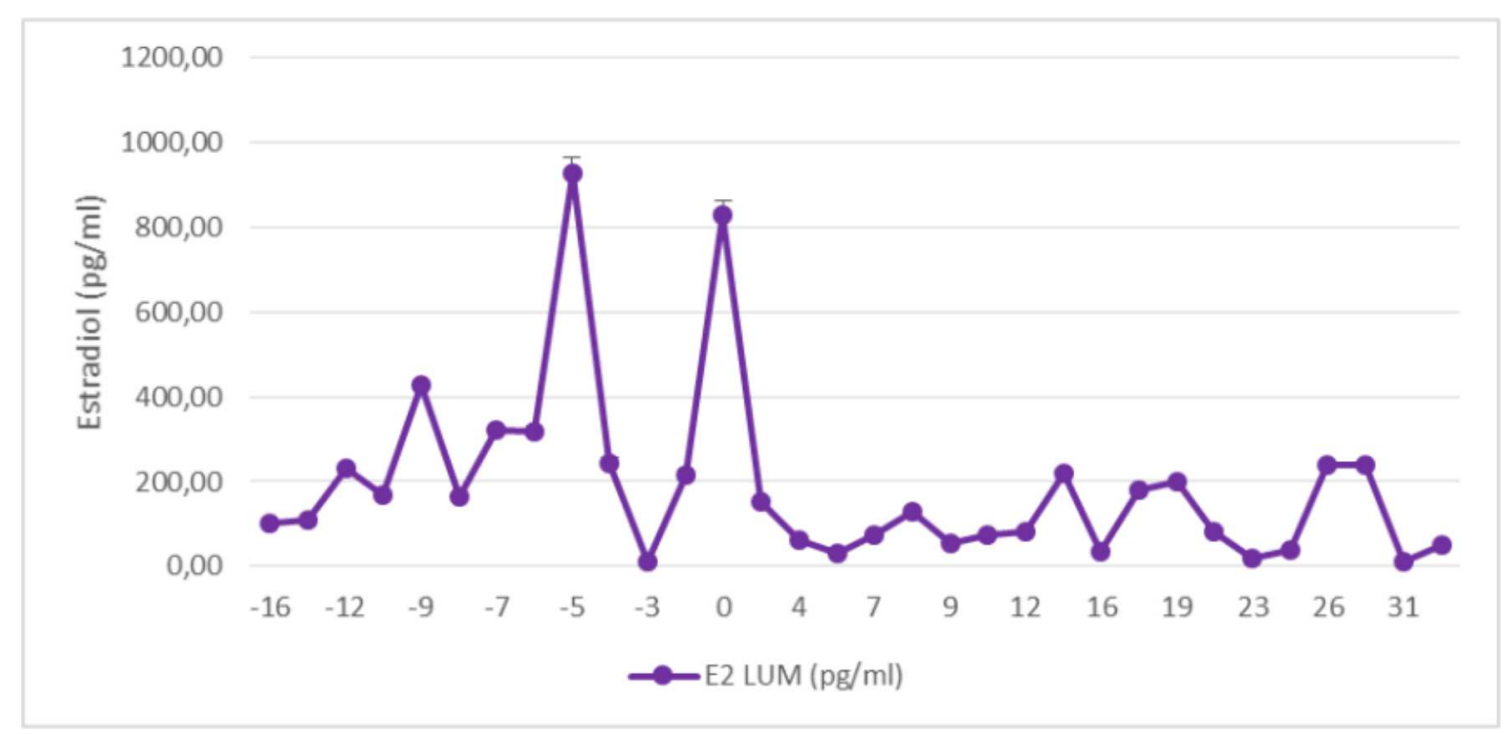


Gráfico 15 - Representação gráfica dos valores médios ( $\pm E P M)$ de progesterona dosado por radioimunoensaio e Luminex®, nas fases de proestro/estro e na fase de diestro.

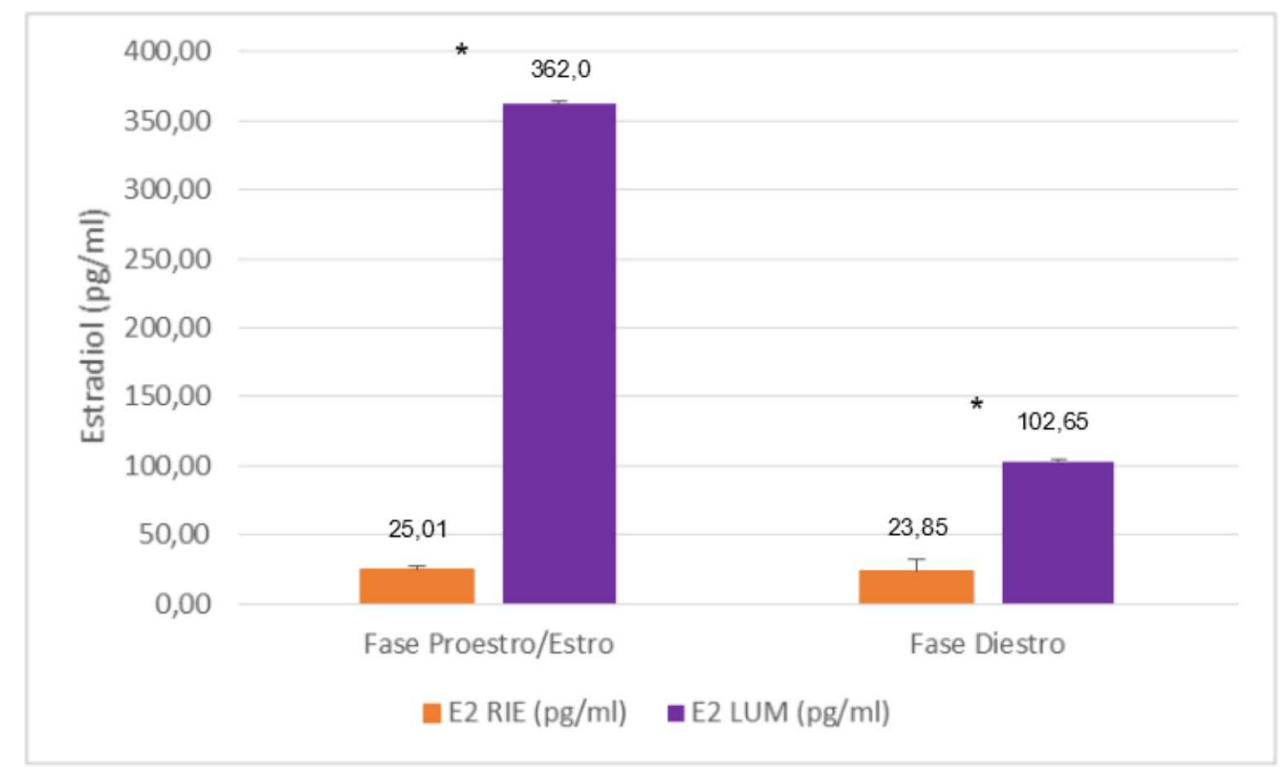

* Diferença significativa entre as médias de progesterona na fase de proestro/estro e diestro

O gráfico das medias de estradiol, tanto para as amostras dosadas por radioimunoensaio, como para 0 Luminex ${ }^{\circledR}$, não apresentaram 0 padrão fisiológico esperado, isto pode ter ocorrido pois as cadelas apresentaram uma variação no tempo de proestro/estro entre elas (variação de 2 a 16 dias), e também a quantidade de animais no experimento provavelmente foi insuficiente para demonstrar claramente o aspecto fisiológico esperado, pois quando analisadas individualmente, fica claro, na maioria dos animais a diferença entre as fases de proestro/estro e diestro, tanto nas amostras dosadas por RIE, quanto por Luminex ${ }^{\circledR}$, conforme demonstram os gráficos abaixo. O gráfico 16 representa os valores de estradiol e progesterona por RIE e por LUM, em ambas as metodologias foi possível verificar o aspecto fisiológico esperado para a fase de proestro/estro e no diestro no animal A. o gráfico 17 representa o animal B. pelo método RIE é possível verificar a o aspecto fisiológico esperado para a fase de proestro/estro e diestro. No LUM, também é possível detectar o aumento da progesterona após o D0 e a diminuição do estradiol após o mesmo período, com exceção do ponto D-3 que pode ser considerado um ponto outlier. No gráfico 18 (Animal C), a representação fisiológica em ambas as metodologias fica bem clara, o que não ocorre no gráfico 19, onde o 
animal D apresenta quadro fisiológico apenas pelo RIE, sendo no LUM, o estradiol não apresenta curva padrão esperado. O mesmo ocorre no animal $\mathrm{E}$ (gráfico 20) e no animal $F$ (gráfico 21). No gráfico 22 (animal G), apesar da discreta diminuição do estradiol pelo RIE, é possível detectar sua diminuição após o D0. No LUM esta diminuição é mais acentuada. Apesar das curvas de progesterona em ambas as metodologias serem diferentes, ambas representam o seu aumento após o D0.

Gráfico 16 - Representação gráfica dos valores de estradiol e progesterona obtidos pelo RIE e pelo LUM do animal A.
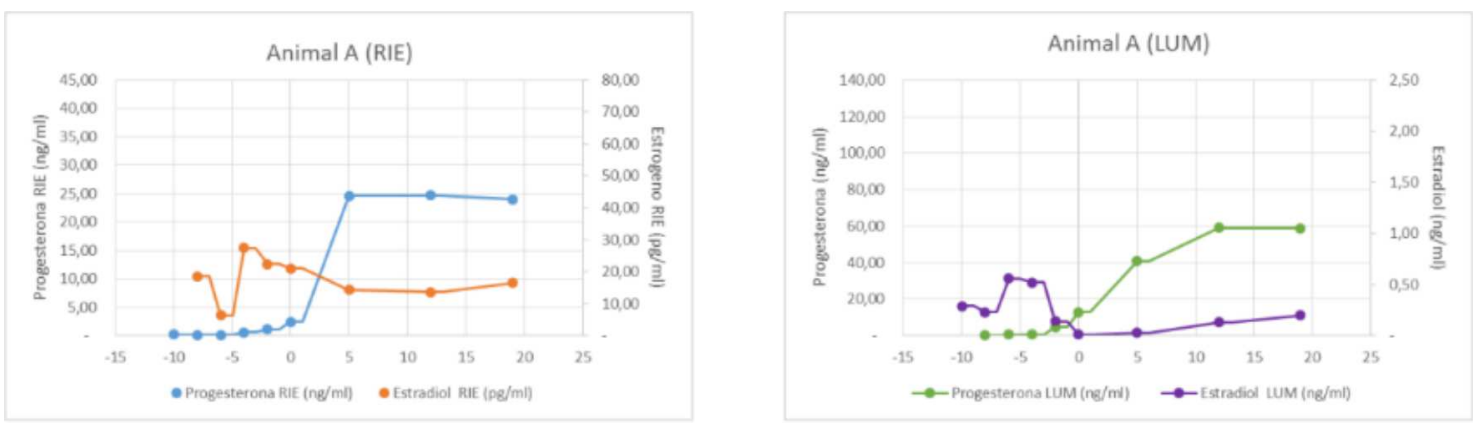

Gráfico 17 - Representação gráfica dos valores de estradiol e progesterona obtidos pelo RIE e pelo LUM do animal B.
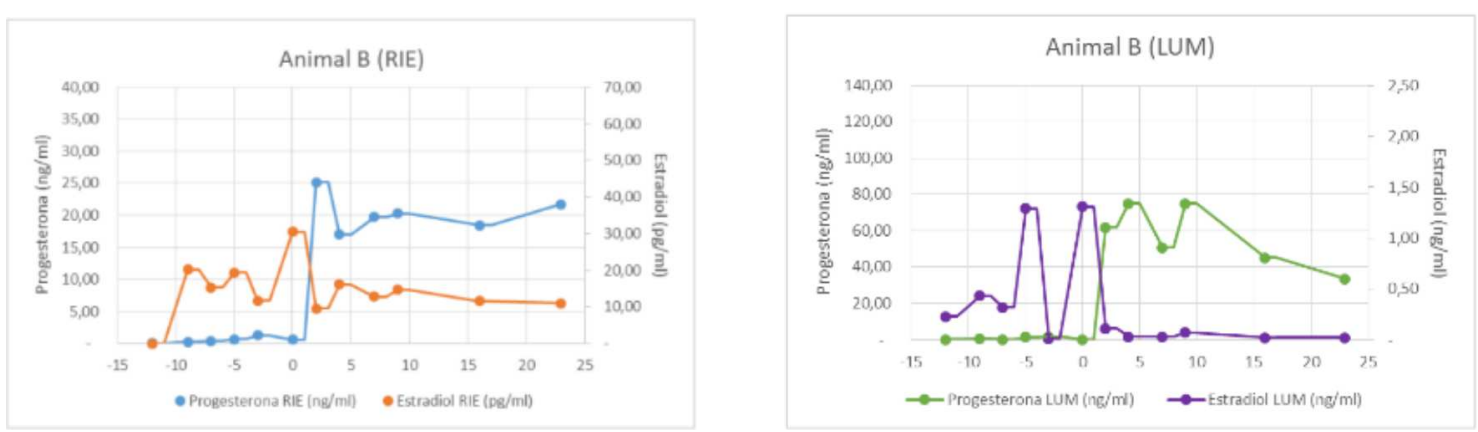
Gráfico 18 - Representação gráfica dos valores de estradiol e progesterona obtidos pelo RIE e pelo LUM do animal C.
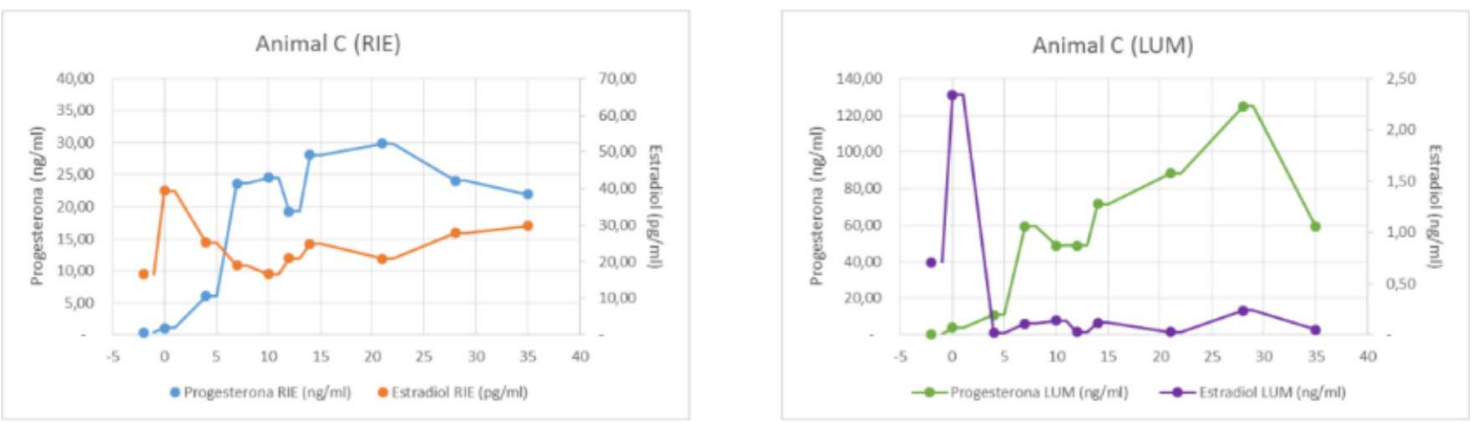

Gráfico 19 - Representação gráfica dos valores de estradiol e progesterona obtidos pelo RIE e pelo LUM do animal D.
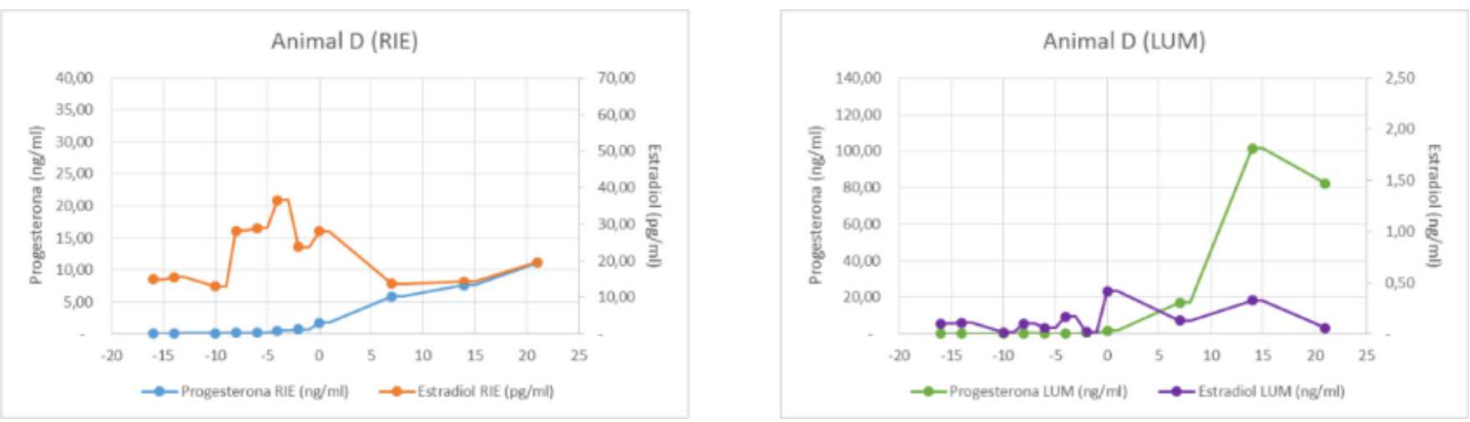

Gráfico 20 - Representação gráfica dos valores de estradiol e progesterona obtidos pelo RIE e pelo LUM do animal E.
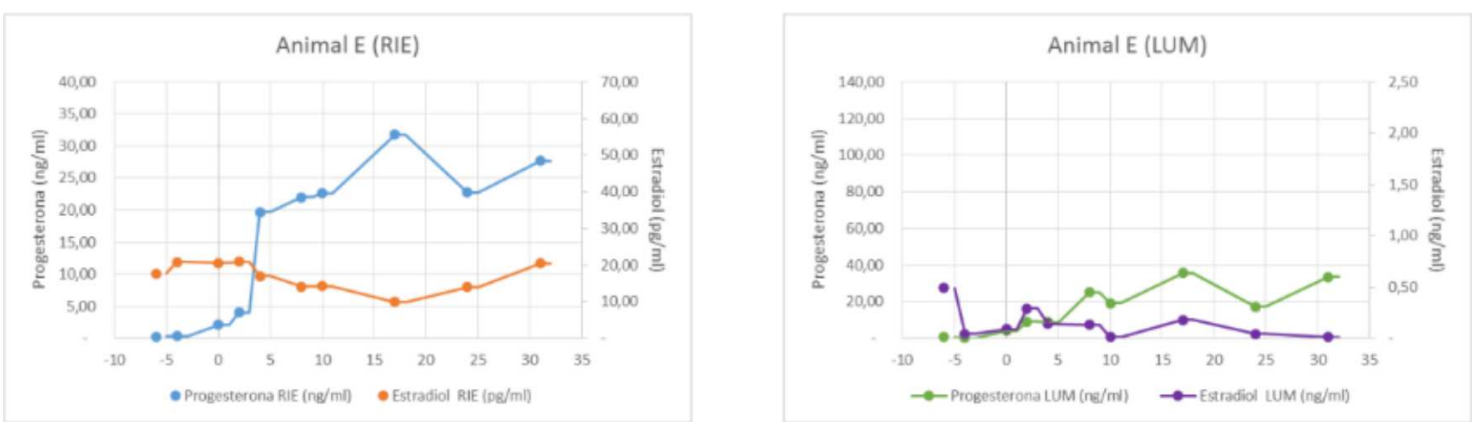
Gráfico 21 - Representação gráfica dos valores de estradiol e progesterona obtidos pelo RIE e pelo LUM do animal F.
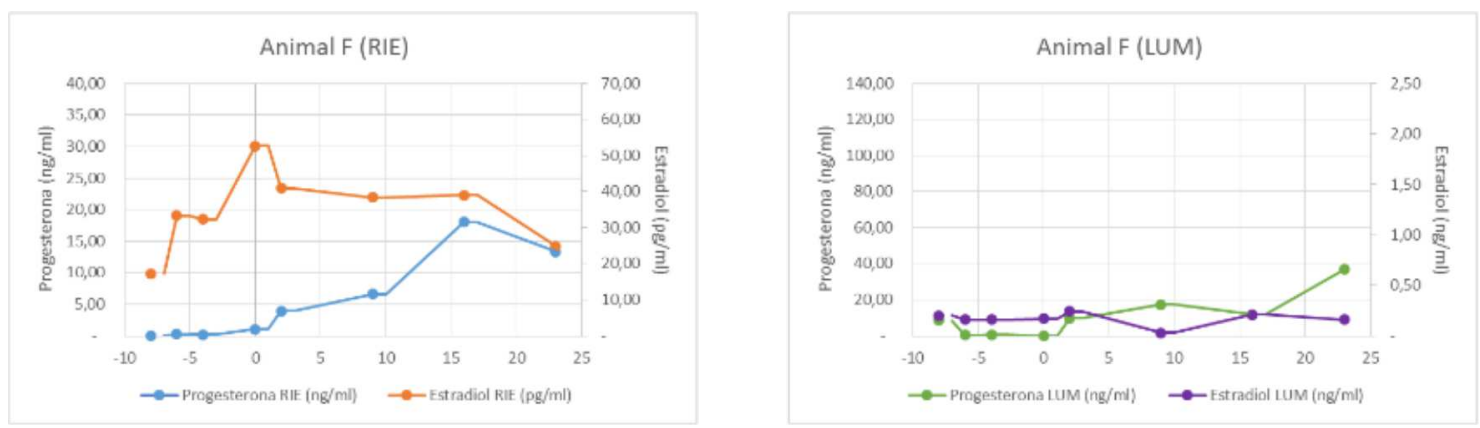

Gráfico 22 - Representação gráfica dos valores de estradiol e progesterona obtidos pelo RIE e pelo LUM do animal G.
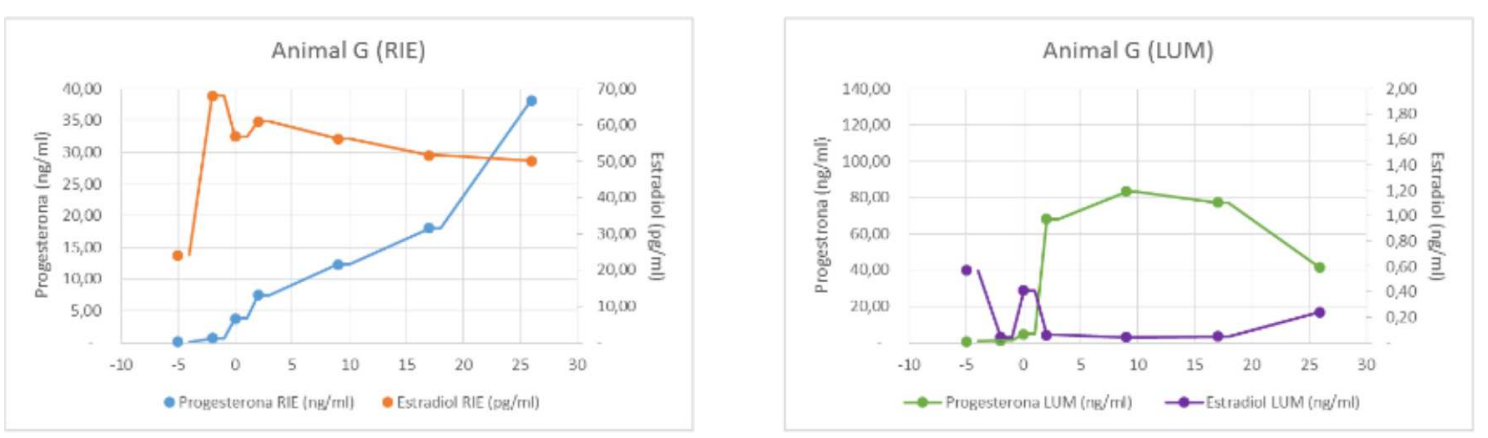

\subsection{Correlação entre Estradiol por RIE e Luminex ${ }^{\circledR}$}

Para a correlação dos métodos realizados para dosagem de estradiol, embora o teste de Kolmogorov-Smirnov tenha apontado para uma distribuição de dados compatíveis com a normalidade, o teste de Bartlett apontou para uma heterogenicidade de variâncias. Tendo-se optado, portanto, pelo teste de correlação de Spearman, o qual revelou um índice de correlação de apenas $r=0,2 \%$ com $p=0,14$, e, portanto, a correlação não foi significativa (gráfico 16). O coeficiente de correlação de Pearson foi calculado mesmo com uma heterogenicidade de variância indicada pelo teste de Bartlett, sendo o coeficiente de correlação $r=0,1 \%$ com $p=0,43$, não havendo correlação, confirmando o relatado anteriormente. 
Gráfico 23 - Representação gráfica da correlação de Spearman obtida entre o estradiol dosado por RIE e por Luminex®

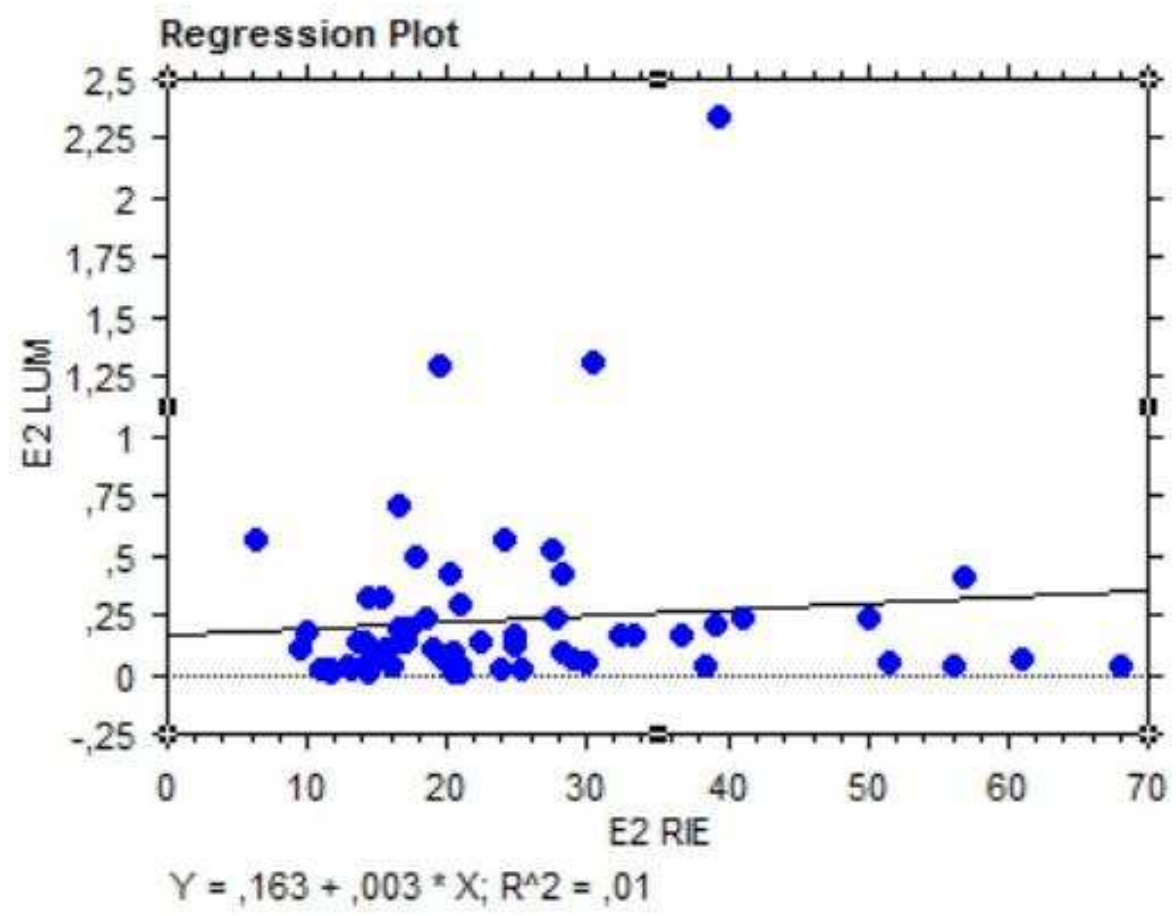

Quando avaliamos o estradiol durante as fases de proestro/estro ( $r=0,09$, $\mathrm{p}=0,63)$ e diestro $(r=0,04, p=0,81)$ também não houve correlação entre as metodologias utilizadas, como demonstrado nos gráficos 17 e 18 
Gráfico 24 - Representação gráfica da ausência de correlação entre o RIE e LUM durante a fase de proestro/estro na mensuração de estradiol

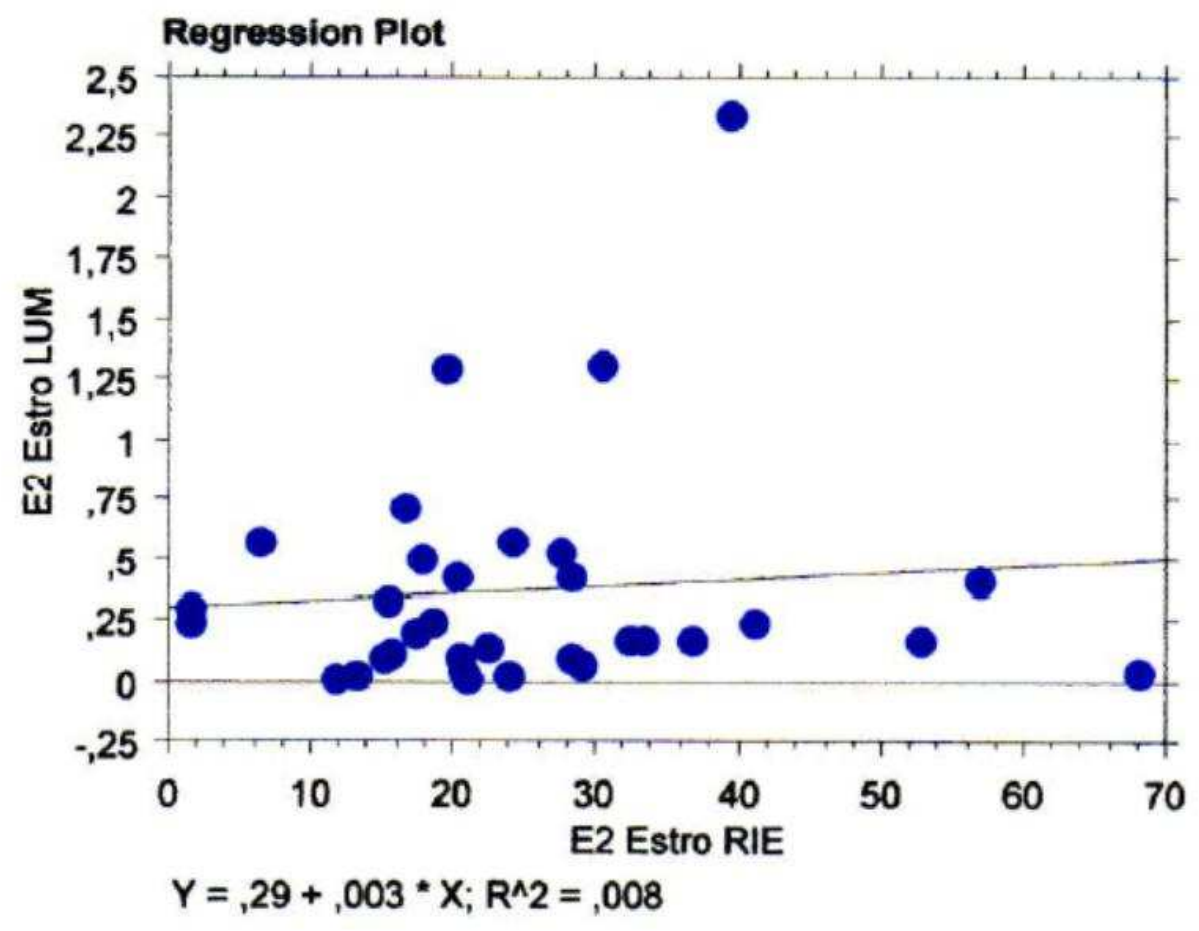

Gráfico 25 - Representação gráfica da ausência de correlação entre RIE e LUM durante a fase de diestro na mensuração de estradiol.

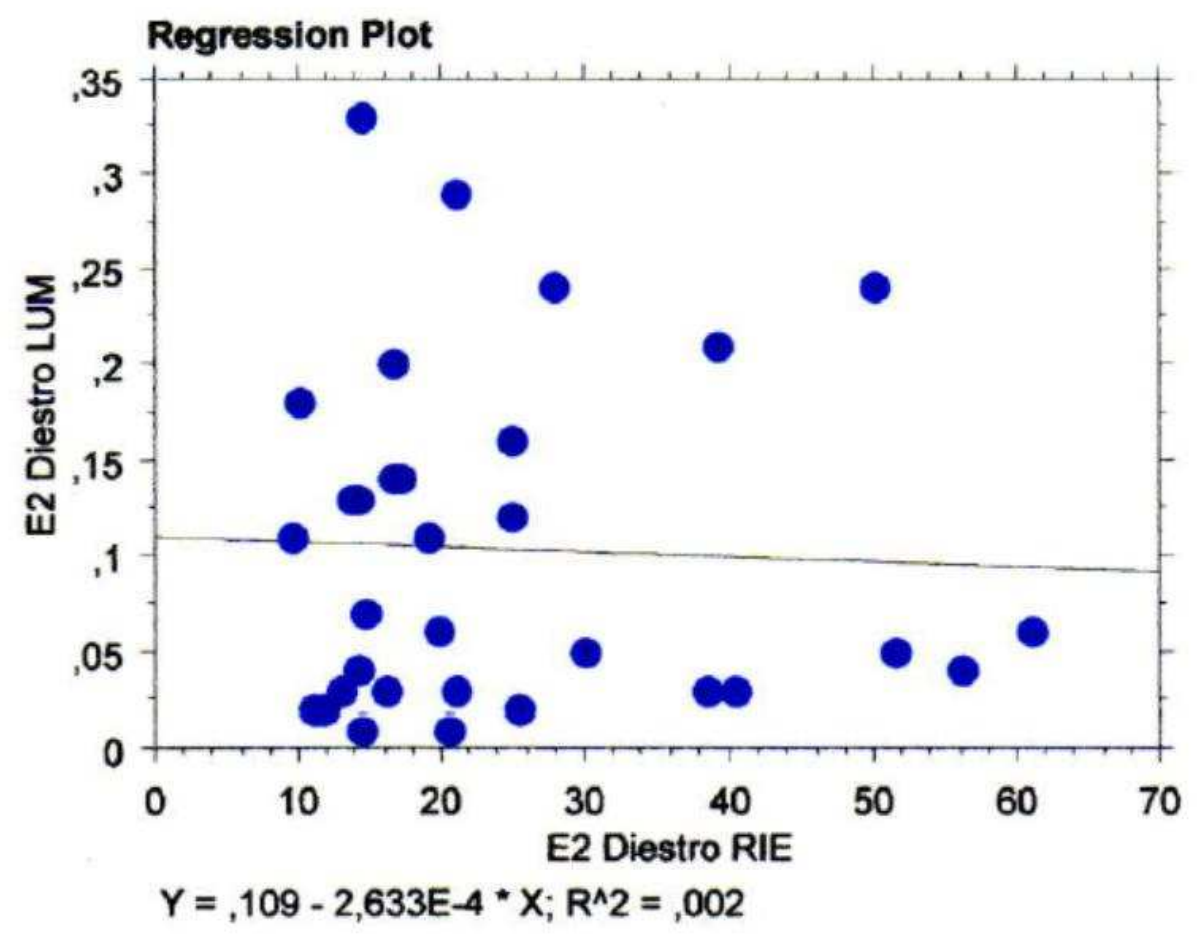




\subsection{Validação Fisiológica}

Os resultados obtidos nas dosagens de progesterona, tanto pelo RIE, quanto pelo Luminex ${ }^{\circledR}$, permitiram diferenciar as flutuações hormonais esperadas para as fases de proestro/estro e no diestro, permitindo a validação fisiológica de ambas as metodologias para os níveis de progesterona.

Ao analisarmos os valores de estradiol para ambas as técnicas, não houve correlação entre as duas metodologias, porem no gráfico de médias globais, há diferença significativa entre as fases, permitindo diferenciar as fases de proestro/estro e de diestro, principalmente pelo Lumine $\mathrm{x}^{\circledR}$.

\section{CONCLUSÕES:}

A dosagem de progesterona por RIE confirmou os dados fisiológicos esperados para a espécie em questão. Mesmo com valores maiores, o Lumine ${ }^{\circledR}$ também apresentou as mesmas caraterísticas esperadas para os níveis de progesterona nas fases de proestro/estro e no diestro. Estes valores podem ser atribuídos à extração necessária para a dosagem pelo Luminex ${ }^{\circledR}$, necessitando, portanto, de um valor de referência diferenciado para o hormônio em questão. Os valores de estradiol dosados por ambas as técnicas, não foram compatíveis com o esperado fisiologicamente, exceto quando analisados à partir de suas médias globais por fases. Novos estudos de validação laboratorial serão necessários para confirmar a validação fisiológica observada neste trabalho, particularmente no que diz respeito ao perfil da progesterona. Pode-se concluir ainda que os valores de referência para o Luminex ${ }^{\circledR}$ devem ser diferentes dos valores de referência obtidos pelo RIE, tanto para progesterona como para o estradiol. 


\section{REFERÊNCIAS}

BAK, M. J.; ALBRECHTSEN, N.W.; PEDERSEN, J.; HARTMANN, B.;

CRISTENSEN, M.; VILSBOLL, T.; KNOP, F.P.; DEACON, C.F.; DRAGSTED, L.O.; HOLST, J.J. Specificity and sensitivity of commercially available assays for glucagon and oxyntomodulin measurement in humans. European Journal of Endocrinology/European Federation of Endocrine Societies, v. 170, ํo 4, p. 529-538, 2014a

BAK, M. J.; WEWER ALBRECHTSEN, N.J.; PEDERSEN, J.; KNOP, F.K.; VISBOLL, T.; JORGENSEN, N.B.; HARTMANN, B.; DEACON, C. F.; DRAGSTES, L. O.; HOLST, J. J. Specificity and sensitivity of commercially available assays for glucagon-like peptide-1 (GLP-1): Implications for GLP-1 measurements in clinical studies. Diabetes, Obesity \& Metabolism, v. 16, no 11 , p. $1155-1164,2014 b$

BERSON, S. A., YALOW, R. S., BAUMAN, A., ROTHSCHILD, M. A., NEWERLYK. Insulin-I131 metabolism in human subjects: Demonstration of insulin binding globulin in the circulation of insulin treated subjects. The Journal of Clinical Investigation, v. 35, ํㅡㄹ, p. 170-190, 1956

CHRISTOPHER-HENNINGS, J.; ARAUJO, K.P.C.; SOUZA, C.J.H.; FANG, Y.; LAWSON, S.; NELSON, E.A.; CLEMENT, T.; DUNN, M.; LUNNEY, J.K. Opportunities for bead-based multiplex assays in veterinary diagnostic laboratories. Journal of Veterinary Diagnostic Investigations, v. 25, no 6, p. 671:691, 2013.

CONCANNON, P. W. Reproductive cycles of the domestic bitch. Animal Reproduction Science, v. 124, p. 200-210, 2011.

CONCANNON, P.W. Induction of fertile oestrus in anestrous dog by constant infusion oh $\mathrm{GnRH}$ agonist. Journal Reproduction Fertility Suppl. v. 39, p. 149-160, 1989.

CONCANNON, P.W. The physiology of ovarian cycles, pregnancy and parturition in the domestic dog. Proceeding of the Society for Theriogenology, 1987. p.159.

DE GIER, J.; KOOISTRA, H.S.; DJAJADININGRAT-LAANEN, S.C.; DIELMAN, S.J.; OKKENS, A.C. Temporal relations between plasma concentrations of luteinizing hormone, follicle-stimulating hormone, estradiol-17 $\beta$, progesterone, prolactin and $\alpha$-melanocyte-stimulating hormone during the follicular, ovulatory, and early luteal phase in the bitch. Theriogenology, v. 65, p. 1349-1359, 2006

DERUSSI, A. A.; LOPES, M. D. Fisiologia da ovulação, da fertilização e do desenvolvimento embrionário inicial na cadela. Revista Brasileira de Reprodução Animal. v. 33, n. 4, p. 231-237, 2009. 
ELSHAL, M. F.; MCCOY, J. P. Multiplex bead array assays: Performance evaluation and comparison of sensitivity to ELISA. Methods, v. 38, p. 317-323, 2006.

ENGLAND, G.C.; CONCANNON, P.W. Determination of the optimal breeding time in the bitch: Basic considerations. In CONCANNON,P.W; ENGLAND, G.; VERSTEGEN, III.J.; LINDE FORSBERG, C. Recent advances in small animal reproduction. Ithaca, [s.n.] 2002. Disponivel em $<$ http://ivis.org/advances/Concannon/england2/chapter frm.asp? LA=1>. Acesso em 12/06/2015.

ENGVALL, E.; PERLMANN, P. (1971). Enzyme-linked immunosorbent assay (ELISA). Quantitative assay of immunoglobulin G. Immunochemistry, v. 8, n. 9 , p. 871-874.

EVANS, H. M.; COLE, H. H. Na introduction to the study of the oestrus cycle in the dog. Memorial University California., 9, 65-118

FELDMAN, E.C.; NELSON, R.W. Canine and feline endocrinology and reproduction. 3 ed. Missouri: Saunders, 2004. 1089p.

FURTADO, P. V. Perfil analitico de estrogenos e progestinas em diferentes matrizes biológicas da espécie ovina (Ovis Aires). 2007. 96f. Tese (Doutorado em Medicina Veterinaria) - Faculdade de Medicina Veterinaria e Zootecnia, Universidade de São Paulo, São Paulo, 2007.

GOODWIN, M.; GOODING, K. M.; REGNIER, F. Sex pheromone in the dog. Science, v. 203, p. 559-561, 1979.

GOPICHANDRAN, N.; EKBOTE, U. V.; WALKER, J. J.; BROOKE, D.; ORSIM, N. M.Multiplex determination of murine seminal fluid cytokine profiles.

Reproduction. n. 131, p. 613-621, 2006.

HORAN, P.K.; WHEELESS, L.L. JR. Quantitative single cells analysis and shorting. Science, p. 198:149, 1977.

HOUSER, B. Bio-Rad's Bio Plex® suspension array system, xMAP technology overview. Archives of Physiology and Biochemistry. v. 118, n. 4, p. 192-196, 2012.

INABA, T.; KAWATE, N.; MORI, J.; TAKAHASHI, S.; MATSUOKA, O. Plasma concentrations of $\mathrm{LH}$, testosterone and estradiol-17 $\beta$ in male beagles dogs.

Japan Journal Animal Reproduction, v. 34, p. 99-104, 1988

JEFFCOATE, I. A.; LINDSAY, F. E. Ovulation detection ant timing of insemination based on hormone concentrations, vaginal cytology ant the endoscopic appearance of the vagina in domestic bitches. Journal Reproduction Fertilily. Suppl, 39, p. 277-287, 1989.

JOHNSTON, S. D.; KUKUSTRITZ, M. V. R.; OLSON, P. N. S. Canine and feline reproduction. Philadelphia: Saunders Company, 2001. 592p. 
KARLSSON, I.; HAGMAN, R.; JOHANNISSON, A.; WANG, L.; KARLSTAM, E.; WERNERSSON, S. Cytokines as immunological markers for systemic inflammation in dogs with pyometra. Reproduction in Domestic Animals. $v$. 47, n. 6, p. 337-341, 2012.

KELLAR, K.L.; IANNONE, M.A. Multiplexed microsphere-based flow cytometric assays. Experimental Hematology, v. 30, n. 1227-1237, 2002.

KUHRE, R. E.; WEWER ALBRECHTSEN, N. J.; HARTMANN, B.; DEACON, C. F.; HOLST, J. J. Measurement of the incretin hormones: glucagon-like peptide1 and glucose-dependent insulinotropic peptide. Journal of Diabetes and its Complications. v. 29, p. 445-450, 2015.

LEVY, X.; FONTBONNE, A. Determining the optimal time of mating in bitches: particularities. Revista Brasileira de Reprodução Animal, v.31, n.1, p.128134, 2007.

LISI, P.J.; HUANG, C.W.; HOFFMAN, R.A.; TEIPEL, J.W. A fluorescence immunoassay for soluble antigens employing flow cytometric detection. Clinica Chimica Acta, v. 120, p. 1714, 1982.

LUMINEX MEETING, 2013, Barueri. Anais... Barueri: Milliplex, 2013.

MILLIPORE. Steroid/thyroid hormone magnetic bead panel. 2013.

OKKENS, A.C.; BEVERS, M.M.; DIELEMAN, S.J.; WILLEMSE, A.H. Evidence for prolactin as the main luteotrophic factorin the cyclic dog. Vet Quartely. v. 12, n. 4, p. 193-201, 1990.

OKKENS, A.C.; KOOISTRA, H.S. Anestrous in the dog: a fascinating story. Reproduction Domestic Animal. v. 41, n. 4, p. 291-296, 2006.

ONCLIN, K.; MURPHY, B.; VERSTEGEN, J.P. Comparisons of estradiol, LH and FSH patterns in pregnant and nonpregnant beagle bitches.

Theriogenology, v. 57, p. 1957-1972, 2002.

RIJNBERK, A.; KOOISTRA, H.S.; MOL, J.A. Endocrine diseases in dogs and cats: similarities and differences with endocrine diseases in humans. Growth Hormone and IGF Research. v. 13, p. S158-S164, 2003.

RODRIGUES, B.A.; RODRIGUES, J.R. Endocrinologia reprodutiva na cadela. Clínica Veterinária. v.40, p. 50-58, 2002.

ROTA, A., MOLLO, A., MARINELLI, L., GABAI, G., VINCENTI, L. Evaluation of Cabergoline and Buserelin efficacy for oestrous induction in the bitch.

Reproduction Domestic Animal. v. 38, p. 440-443, 2003.

ROTA, A.; VERONESI, M.C.; VOLPE, S.; RICCARDI, A.; BATTOCCHIO, M. Estradiol-17ß, progesterone and testosterone plasma concentrations during estrus in the bitch. Veterinary Research Communications, v. 31, n. 1, p. 197199,2007 
RYAN, E.A.; ENNS, L. Role of gestacional hormones in the induction of insulin resistence. Journal of Clinical Endocrinology and Metabolism. v. 67, p. 341, 1988.

SANGHA, G. K.; SHARMA, R. K.; GURAYA, S. S. Biology of corpus luteum in small ruminants. Small Ruminant Reseach, v. 43, p. 53-64, 2002.

SENGER, P.L. Pathways to pregnancy and parturition. 2 rev. ed. USA: Current Conceptions, 2005. 373p.

SILVA, L. D.; SILVA, A. R.; CARDOSO, R. C. S. Inseminação artificial em aães. In: GONÇALVES, P. B. D.; FIGUEIREDO, J. R.; FREITASV. J. F. Biotecnicas aplicadas a reprodução animal. São Paulo: Varela, 2001. p. 69-95.

THOREL; LARSON, S. M. Radioimmunoassay and related techniques. Saint Louis: Mosby Company, 1978. 289p.

VANNUCCHI, C.I.; SATIZINGER, S.; SANTOS, S.E.C. Técnica de citologia vaginal como método diagnostico da fase do ciclo estral em cadelas. Clínica Veterinária, v. 9, p. 14-19, 1997. 